\title{
Comparative Pathogenomics of Bacteria Causing Infectious Diseases in Fish
}

\author{
Ponnerassery S. Sudheesh, Aliya Al-Ghabshi, Nashwa Al-Mazrooei, and Saoud Al-Habsi
}

Microbiology Laboratory, Fishery Quality Control Center, Ministry of Agriculture and Fisheries Wealth, P.O. Box 427, 100 Muscat, Oman

Correspondence should be addressed to Ponnerassery S. Sudheesh, sudheeshps@yahoo.com

Received 6 February 2012; Accepted 20 March 2012

Academic Editor: Shinji Kondo

Copyright ( $(2012$ Ponnerassery S. Sudheesh et al. This is an open access article distributed under the Creative Commons Attribution License, which permits unrestricted use, distribution, and reproduction in any medium, provided the original work is properly cited.

\begin{abstract}
Fish living in the wild as well as reared in the aquaculture facilities are susceptible to infectious diseases caused by a phylogenetically diverse collection of bacterial pathogens. Control and treatment options using vaccines and drugs are either inadequate, inefficient, or impracticable. The classical approach in studying fish bacterial pathogens has been looking at individual or few virulence factors. Recently, genome sequencing of a number of bacterial fish pathogens has tremendously increased our understanding of the biology, host adaptation, and virulence factors of these important pathogens. This paper attempts to compile the scattered literature on genome sequence information of fish pathogenic bacteria published and available to date. The genome sequencing has uncovered several complex adaptive evolutionary strategies mediated by horizontal gene transfer, insertion sequence elements, mutations and prophage sequences operating in fish pathogens, and how their genomes evolved from generalist environmental strains to highly virulent obligatory pathogens. In addition, the comparative genomics has allowed the identification of unique pathogen-specific gene clusters. The paper focuses on the comparative analysis of the virulogenomes of important fish bacterial pathogens, and the genes involved in their evolutionary adaptation to different ecological niches. The paper also proposes some new directions on finding novel vaccine and chemotherapeutic targets in the genomes of bacterial pathogens of fish.
\end{abstract}

\section{Introduction}

Genome sequencing has provided us with powerful insights into the genetic makeup of the microbial world. The microbial genomics today has progressed from the long drawnout individual genome sequencing projects in the past to a level of technological advancement, where sequencing and comparing the genomes of several strains of a single pathogen is accomplished in a very short period of time $[1,2]$. We are currently passing through a period of explosive developments in the field and an overwhelming glut in the genome sequence data of microorganisms. To date, over 1800 microbial genomes have been published and the sequencing of more than 5200 microbial genome are in different stages of completion (http://www.ncbi.nlm.nih.gov/genomes/lproks.cgi).

The genomics information has categorically disproved the earlier thinking that microbial genomes are static and has demonstrated that genomic evolutionary processes are much more flexible and dynamic than previously thought. This has led to the emergence of new ideas such as "uprooting the tree of life" and the concept of "horizontal genomics" [3-8]. This new thinking about microbial genome evolution has emerged from the observations of lineage-specific genome reduction and horizontal gene transfer (HGT), frequently occurring in bacterial genomes. Increasingly, genome sequencing projects have identified an unexpected level of diversity among bacteria, which can often be linked to recombination and gene transfer between a variety of prokaryotic organisms.

There is large variation in size and content of bacterial genomes between different genera and species, and also among strains of the same species. Known genome sizes of bacteria range from under 0.6 to 10 megabases $(\mathrm{Mb})$. The smallest bacterial genomes reported are for the mycoplasmas and related bacteria, with sizes as low as 530 kilobases 


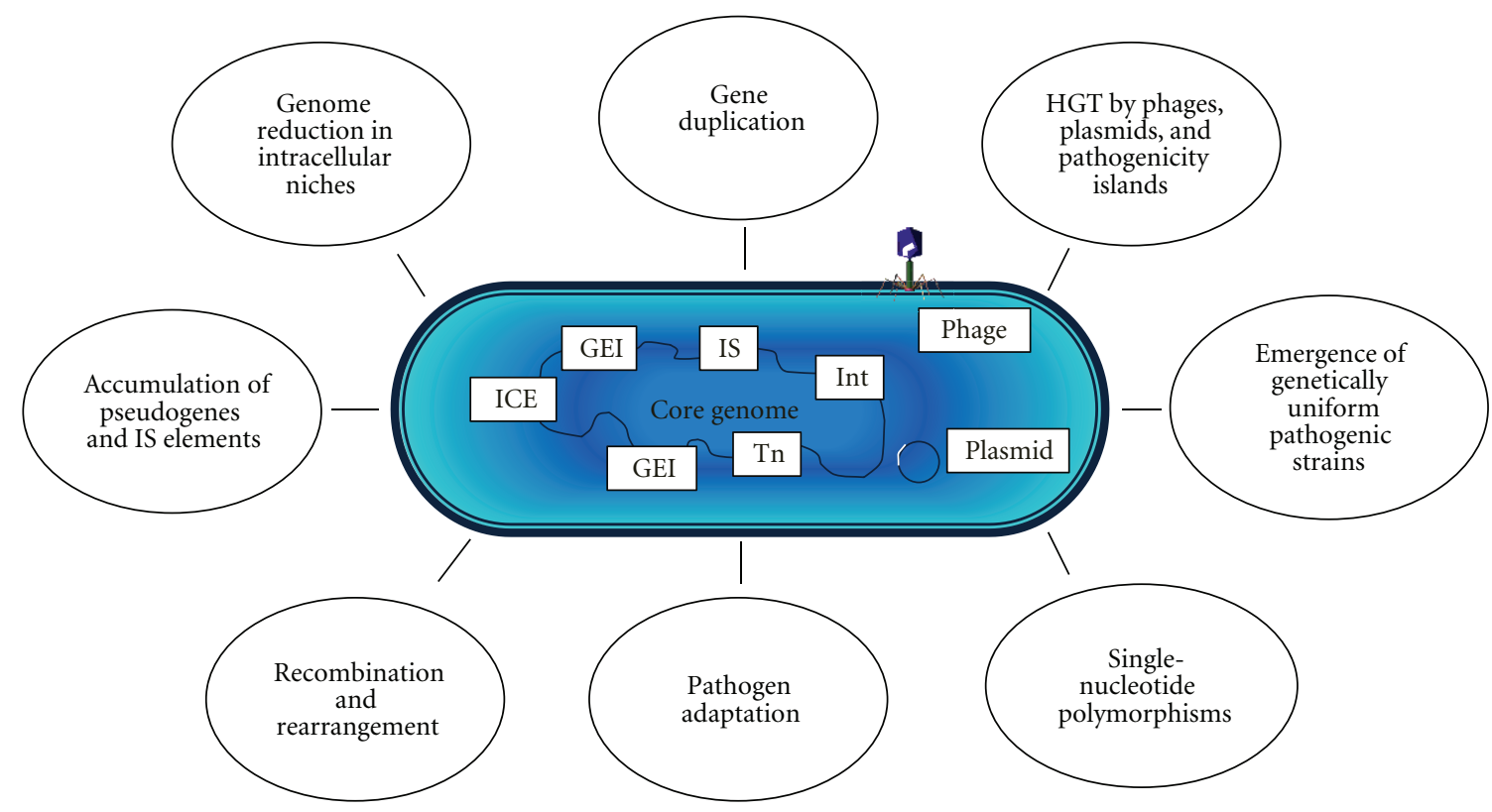

FIGURE 1: Major factors responsible for the pathogenomic evolution of bacteria (modified from [14, 15]; HGT: horizontal gene transfer, GEIs: genomic islands, ICEs: integrative conjugative elements, Int: integrons, Tn: conjugative transposons, IS: IS elements.

[9]. It has been emphasized that the adaptive capability ("versatility") of bacteria directly correlates with genome size [10].

Genome sequencing of bacterial pathogens has produced exciting information on evolutionary relationships between pathogenic and nonpathogenic species and has demonstrated how each has developed special adaptations advantageous for each of their unique infectious lifestyles. In the longer term, an understanding of their genome and biology will enable scientists to design means of disrupting their infectious lifestyles.

The genomes of bacteria are made up of circular or linear chromosomes, extrachromosomal linear or circular plasmids as well as different combinations of these molecules. The functionally related genes are clustered together in very close proximity to each other, and those genes located on the "core" part of the chromosome present a relatively uniform $\mathrm{G}+\mathrm{C}$ content and a specific codon usage. Closely related bacteria generally have very similar genomes [11].

The stability and integrity of the "core" sequences of the genome, however, is often interrupted by the presence of DNA fragments with a $\mathrm{G}+\mathrm{C}$ content and a codon usage markedly different from those of the "core" genome. The "flexible" gene pool or the so-called "mobilome" [12], is created by the acquisition of strain-specific "assortments" of genetic information mainly represented by mobile genetic elements (MGE), such as plasmids, bacteriophages, genomic/pathogenicity islands (GEIs/PAIs), integrons, IS elements (ISEs), and transposons (see Figure 1). The flexible genes scattered in the genome provide the microbes with an additional repertoire of arsenal, for example, resistance to antibiotics, production of toxic compounds as well as other virulence factors [13].
A fundamental question in biology is to define the minimum number of genes or functions to support cellular life. The size of bacterial genomes is primarily the result of two counteracting processes: the acquisition of new genes by gene duplication or by horizontal gene transfer; the deletion of nonessential genes. Genomic flux created by these gains and losses of genetic information can substantially alter gene content. This process drives divergence of bacterial species and eventually adaptation to new ecological niches [16].

Bacterial pathogens are a major cause of infectious diseases and mortality in wild fish stocks and fish reared in confined conditions. Disease problems constitute the largest single cause of economic losses in aquaculture [17]. Concurrent with the rapid growth and intensification of aquaculture, increased use of water bodies, pollution, globalization, and transboundary movement of aquatic fauna, the list of new pathogenic bacterial species isolated from fish has been steadily increasing [18]. In addition, the virulence and host range of existing pathogens has also been increasing, posing considerable challenge to fish health researchers, who are actively looking for more efficient vaccines and therapeutic drugs to combat bacterial fish diseases. The current treatment methods are ineffective and have many practical difficulties.

At the level of host-pathogen interaction, there is considerable pressure on pathogens to adapt to the harsh host environment as well as to adapt and evolve along with the ever changing external environment. The interplay between the host and the pathogen is a complex one, each driven by the need to secure the success of the species. Adaptations by one partner to exploit new environments will often stimulate the other to modify its characteristics to take advantage of the change. As a consequence of this cycle of interaction created by changing environments, new strains of pathogen 
TABLE 1: Currently sequenced genomes of bacterial pathogens of fish.

\begin{tabular}{|c|c|c|c|c|c|c|c|}
\hline Organisms & $\begin{array}{l}\text { Size } \\
(\mathrm{Mb})\end{array}$ & $\mathrm{CDS}^{* *}$ & $\begin{array}{l}\text { Unknown/ } \\
\text { Hypothetical } \\
\text { genes }(\%)\end{array}$ & $\begin{array}{c}\text { Pseudogenes } \\
\text { prophages, } \\
\text { ISE/GEI }\end{array}$ & $\begin{array}{c}\% \\
\text { GC }\end{array}$ & Chromosomes & Plasmids \\
\hline Vibrio anguillarum 775 serotype $\mathrm{O} 1$ & 4.117 & 3880 & 26 & 92 & 44.3 & 2 & 1 \\
\hline Vibrio anguillarum 96F serotype $\mathrm{O} 1$ & 4.065 & 3766 & 26 & 38 & 42 & 2 & 0 \\
\hline Vibrio anguillarum $\mathrm{RV} 22$ serotype $\mathrm{O} 2 \beta$ & 4.022 & 3949 & 26 & 68 & 43.1 & 2 & 0 \\
\hline Vibrio ordalii ATCC 33509 & 3.415 & 3281 & - & 31 & 43.3 & 2 & 0 \\
\hline Vibrio harveyi ATCC BAA-1116* & 6.054 & - & - & - & 45.4 & 2 & 1 \\
\hline Vibrio vulnificus YJ016 biotype 1 & 5.26 & 5028 & 34 & - & 46.1 & 2 & 1 \\
\hline Vibrio splendidus strain LGP32 & 4.974 & 4498 & 24.8 & - & 43.8 & 2 & 0 \\
\hline Aliivibrio salmonicida strain LFI1238 & 4.655 & 4286 & - & 1179 & 38.3 & 2 & 4 \\
\hline Flavobacterium psychrophilum JIP02/86 & 2.862 & 2432 & 45.3 & 94 & 32.5 & 1 & 1 \\
\hline Flavobacterium branchiophilum FL-15 & 3.56 & 2867 & - & 54 & 32.9 & 1 & - \\
\hline Flavobacterium columnare ATCC 49512* & 3.2 & 2896 & - & - & 32.0 & 1 & - \\
\hline Edwardsiella tarda EIB202 & 3.76 & 3486 & 28 & 97 & 59.7 & 1 & 1 \\
\hline Edwardsiella ictaluri $93-146^{*}$ & 3.812 & 3783 & - & 100 & 57.4 & 1 & - \\
\hline Aeromonas hydrophila ATCC 7966 & 4.744 & 5195 & 27.7 & 7 & 61.5 & 1 & 0 \\
\hline Aeromonas salmonicida A449 & 4.702 & 4437 & - & 258 & 58.5 & 1 & 5 \\
\hline Aeromonas veronii Strain B565 & 4.551 & 4057 & - & - & 58.7 & 1 & - \\
\hline A. caviae Ae398 & 4.43 & - & - & 6 & 61.4 & 1 & 1 \\
\hline Renibacterium salmoninarum ATCC 33209 & 3.155 & 3507 & 25.3 & 151 & 56.3 & 1 & 0 \\
\hline Streptococcus parauberis & 2.143 & 2641 & 21.3 & - & 35.6 & 1 & 0 \\
\hline Lactococcus garvieae UNIUD074 & 2.172 & 2101 & 21.8 & 224 & 38.7 & 1 & 0 \\
\hline Mycobacterium marinum $\mathrm{M}$ & 6.636 & 5424 & 26 & 65 & 62.5 & 1 & 1 \\
\hline
\end{tabular}

* Unpublished.

** Coding sequences.

will evolve. Over time, these strains may emerge as new species with characteristic disease symptoms.

The use of antibiotics to control fish diseases has met with limited success and has the potential danger of antibiotic resistance development in aquatic bacteria (World Health Organization antimicrobial resistance fact sheet 194, http://www.who.int/inf-fs/en/fact194.html) [19]. As aquaculture is one of the fastest growing food production industries in the world, demand for sustainable ways of combating fish diseases is gaining significance. There is tremendous scope for developing novel vaccines and therapeutic drugs against bacterial fish pathogens.

Genomic evolution and adaptive strategies of bacterial fish pathogens are poorly understood and lags far behind that of human and terrestrial animal pathogens. A detailed knowledge of the genome sequences of bacterial fish pathogens and how the genomes of the pathogenic species or strains evolved from nonpathogenic ancestors or counterparts will help us better understand their pathogenicity mechanisms and strategies of host adaptations. This information will help identifying novel vaccine and drug targets in the genomes of pathogens.

Recently, genome sequencing of a number of bacteria pathogenic to fish and other aquatic organisms have been completed. The genome sequence and genome characteristics of important bacterial fish pathogens completed and published to date are summarized in Table 1.
The main aim of this paper is to put together and summarize the scattered genome sequencing information on important bacterial fish pathogens available in the literature to date. We sincerely believe that this paper will provide a genomic perspective on the adaptive evolutionary strategies of bacterial fish pathogens in different ecological niches and will help better understand the virulence mechanisms and pathogenesis of infections. It is hoped that this will lead to finding the most appropriate vaccine and therapeutic drug targets in the genomes and developing efficient control and treatment methods for fish diseases.

\section{Bacterial Pathogens of Fish}

Although pathogenic species representing majority of existing bacterial taxa have been implicated in fish diseases, only a relatively small number of pathogens are responsible for important economic losses in cultured fish worldwide. Major bacterial pathogens responsible for infectious disease outbreaks in different species of fish are listed in Table 2. Major groups of bacteria causing infectious diseases in fish and the important genome characteristics of these bacteria are described in the following sections.

\section{Vibrios}

Bacteria in the genus Vibrio are mainly pathogenic to marine and brackish water fish. However, they are occasionally 
TABLE 2: Major bacterial pathogens of economically important fish.

\begin{tabular}{|c|c|c|}
\hline Causative agent/species & Disease & Main host fish \\
\hline \multicolumn{3}{|l|}{ Gram-negatives } \\
\hline Vibrio anguillarum & Vibriosis & $\begin{array}{l}\text { Salmonids, turbot, sea bass, striped bass, eel, } \\
\text { ayu, cod, and red sea bream }\end{array}$ \\
\hline $\begin{array}{l}\text { Aliivibrio salmonicida } \\
\text { (formerly Vibrio salmonicida) }\end{array}$ & Vibriosis & Atlantic salmon, cod \\
\hline Vibrio vulnificus & Vibriosis & Eels, tilapia \\
\hline Vibrio ordalii & Vibriosis & Salmonids \\
\hline $\begin{array}{l}\text { Vibrio carchariae } \\
\text { (syn.: Vibrio harveyi) }\end{array}$ & Vibriosis, infectious gastroenteritis & $\begin{array}{l}\text { Shark, abalone, red drum, sea bream, sea } \\
\text { bass, cobia, and flounder }\end{array}$ \\
\hline $\begin{array}{l}\text { Moritella viscosa } \\
\text { (formerly Vibrio viscosus) }\end{array}$ & Winter ulcer & Atlantic salmon \\
\hline $\begin{array}{l}\text { Photobacterium damselae subsp. piscicida } \\
\text { (formerly Pasteurella piscicida) }\end{array}$ & $\begin{array}{l}\text { Photobacteriosis } \\
\text { (pasteurellosis) }\end{array}$ & $\begin{array}{l}\text { Sea bream, sea bass, sole, striped bass, and } \\
\text { yellowtail }\end{array}$ \\
\hline Pasteurella skyensis & Pasteurellosis & Salmonids and turbot \\
\hline $\begin{array}{l}\text { Tenacibaculum maritimum } \\
\text { (formerly Flexibacter maritimus) }\end{array}$ & Flexibacteriosis & $\begin{array}{l}\text { Turbot, salmonids, sole, sea bass, gilthead } \\
\text { sea bream, red sea bream, and flounder }\end{array}$ \\
\hline Flavobacterium psychrophilum & Coldwater disease & Salmonids, carp, eel, tench, perch, ayu \\
\hline Flavobacterium branchiophila & Bacterial gill disease & $\begin{array}{l}\text { A broad range of cultured cold water and } \\
\text { warm water salmonid and nonsalmonid } \\
\text { fishes }\end{array}$ \\
\hline Flavobacterium columnare & Columnaris disease & $\begin{array}{l}\text { cyprinids, salmonids, silurids, eel, and } \\
\text { sturgeon }\end{array}$ \\
\hline Pseudomonas anguilliseptica & Pseudomonadiasis, winter disease & Sea bream, eel, turbot, and ayu \\
\hline Aeromonas salmonicida & Furunculosis & $\begin{array}{l}\text { salmon, trout, goldfish, koi and a variety of } \\
\text { other fish species }\end{array}$ \\
\hline $\begin{array}{l}\text { Aeromonas hydrophila } \\
\text { Aeromonas veronii Biovar Sobria } \\
\text { Aeromonas sobria Biovar Sobria } \\
\text { (Motile aeromonads) }\end{array}$ & $\begin{array}{l}\text { Motile aeromonas septicemia (MAS), } \\
\text { hemorrhagic septicemia, ulcer disease or } \\
\text { red-sore disease, and epizootic ulcerative } \\
\text { syndrome (EUS) }\end{array}$ & $\begin{array}{l}\text { A wide variety of salmonid and } \\
\text { nonsalmonid fish, sturgeon, tilapia, catfish, } \\
\text { striped bass, and eel }\end{array}$ \\
\hline Edwardsiella ictaluri & Enteric septicemia & Catfish and tilapia \\
\hline Edwardsiella tarda & Edwardsiellosis & $\begin{array}{l}\text { Salmon, carps, tilapia, catfish, striped bass, } \\
\text { flounder, and yellowtail }\end{array}$ \\
\hline Yersinia ruckeri & Enteric redmouth & $\begin{array}{l}\text { Salmonids, eel, minnows, sturgeon, and } \\
\text { crustaceans }\end{array}$ \\
\hline Piscirickettsia salmonis & Piscirickettsiosis & Salmonids \\
\hline \multicolumn{3}{|l|}{ Gram-positives } \\
\hline $\begin{array}{l}\text { Lactococcus garvieae } \\
\text { (formerly Enterococcus seriolicida) }\end{array}$ & Streptococcosis or lactococcosis & Yellowtail and eel \\
\hline Streptococcus iniae & Streptococcosis & $\begin{array}{l}\text { Yellowtail, flounder, sea bass, and } \\
\text { barramundi }\end{array}$ \\
\hline Streptococcus parauberis & Streptococcosis & Turbot \\
\hline Streptococcus phocae & Streptococcosis & Atlantic salmon \\
\hline Renibacterium salmoninarum & Bacterial kidney disease & Salmonids \\
\hline Mycobacterium marinum & Mycobacteriosis & Sea bass, turbot, and Atlantic salmon \\
\hline
\end{tabular}

reported in freshwater species as well $[20,21]$. The distribution of vibriosis is worldwide and causes great economic loss to the aquaculture industry [22]. Vibriosis, one of the major bacterial diseases affecting fish, bivalves, and crustaceans, is mainly caused by pathogenic species such as Vibrio anguillarum, V. harveyii (Syn. V. carchariae), V. ordalii, and Alivibrio salmonicida (formerly Vibrio salmonicida) [23, 24].

Other species such as V. vulnificus $[25,26]$ and Moritella viscosa (formerly Vibrio viscosus) [27] have been implicated in fish diseases such as septicemia and winter ulcer, respectively; more pathogenic species have been isolated frequently and reported in the literature [28].

Genome sequences of four major fish pathogenic vibrios, $V$. anguillarum, $V$. ordalii, Aliivibrio salmonicida, and V.vulnificus have been completed and published [29-31]. Generally, they have two chromosomes, one larger and one smaller. The majority of genes that encode cell functions and pathogenic factors are located in the large one. The 
small chromosome usually contains genes for environmental adaptation.

Vibrio anguillarum is the most studied aetiological agent of vibriosis [32]. $V$. anguillarum typically causes a hemorrhagic septicemia. The $\mathrm{O} 1$ and $\mathrm{O} 2$ serotypes are the virulent strains frequently isolated from diseased fish [33, 34]. Many O1 serotype strains harbor $65 \mathrm{~kb}$ pJM1-type plasmids, which carry the siderophore anguibactin biosynthesis and transport genes, a main virulence factor of $V$. anguillarum, while one of the $\mathrm{O} 1$ serotype strains and other serotypes, such as all of the $\mathrm{O} 2$ strains, are plasmidless $[28,35,36]$. The $\mathrm{O} 1$ serotype strains cause disease in salmonid fish, whereas $\mathrm{O} 2 \beta$ strains are usually isolated from cod and other nonsalmonids $[28,32]$.

Vibrio ordalii is a very close relative of V. anguillarum [37] and was previously recognized as $V$. anguillarum biotype 2 . Vibriosis caused by these two species are strikingly different based on histological evidences [38]. V. anguillarum has a special affinity for blood and loose connective tissue, whereas $V$. ordali is mostly present as aggregates in skeletal and cardiac muscles. V. ordalii has a lesser affinity for blood and develops bacteremia only at late stages of disease.

Genomic sequences of three different strains of $V$. anguillarum (the strain 775 containing plasmid pJM1, serotype O1 strain 96F, and plasmidless serotype O2 $\beta$ strain RV22) and $V$. ordali have recently been published [31]. The pJM1 plasmid in the strain 775 contains 65 genes including the anguibactin biosynthesis and transport genes that are unique for the strain.

V. anguillarum 775 contains more transposase genes (about 53) than 96F (about 23), RV22 (about 42), and V. ordalii (about 18).

The genome comparison of $V$. anguillarum serotypes has revealed some interesting differences in the genomic composition, indicating horizontal acquisition of virulence genes and the evolution of different potential virulence mechanisms among the closely related serotypes [31]. The V. anguillarum 96F strain has a type III secretion system 2 (T3SS2) cluster, which is absent in the 775 strain. The T3SS2 genes are highly conserved with other T3SS2 genes reported in $V$. parahaemolyticus, $V$. cholera, and V. mimicus [39-41]. In the 775 strain, three transposase genes are present at the T3SS2 chromosomal location, one of which probably originated from the pJM1, indicating that the gene cluster is inactivated by a transposition, deletion, or inversion event [31]. The 775 strain also contains 10 genomic islands including integrase, transposase, and some novel sequences conferring genomic plasticity to adapt to specific ecological niches.

The strain RV22 genome contains the toxin-antitoxin systems, and genes encoding the accessory $V$. cholerae enterotoxin (Ace) and the Zonula occludens toxin (Zot), which is not present in the 775 strain. The yersiniabactin-like siderophore cluster, which is highly conserved in many Vibrio species and Photobacterium damselae subspecies piscicida [42], is present in strain RV22 and V. ordalii.

A striking feature of $V$. ordali genome is its significant reduction in size $(3.4 \mathrm{Mb})$ compared to the $V$. anguillarum strains $775(4.1 \mathrm{Mb}), 96 \mathrm{~F}(4.0 \mathrm{Mb})$, and RV22 (4.0 Mb). $V$. ordali lacks the $\mathrm{ABC}$ transporter genes, the type VI secretion systems, and the gene for microbial collagenase. The Syp biofilm formation cluster, which is conserved in many Vibrio species such as V. fischeri, $V$. vulnificus, and V. parahaemolyticus $[43,44]$, is present only in $V$. ordalii. Thus, it is probable that the transition of $V$. anguillarum to $V$. ordalii is mediated by genome reductive evolution to become an endosymbiotic organism; $V$. ordali has the smallest genome of all vibrios.

Vibrio vulnificus includes three distinct biotypes. Biotype 1 strains cause human disease, while biotype 2 infects primarily eels, and biotype 3 infections has been associated with persons handling Tilapia, although the source and reservoir of biotype 3 have yet to be identified [45]. In another classification the terms clade 1 and clade 2 are used based on the multilocus sequence typing (MLST) [46]. Biotype 1 strains are present in both clades, whereas biotype 2 strains are present only in clade 1, and biotype 3 strains appear to be a hybrid between clades 1 and 2. Clade 1 strains are most often isolated from environmental samples, while clade 2 strains are mostly associated with human disease and are considered more virulent. Recent comparative genomic analysis of these biotypes or clades has clearly differentiated them based on the possession of an array of clade-specific unique genes including the presence of a virulence-associated genomic island XII in the highly virulent strains [30].

Alivibrio salmonicida (formerly Vibrio salmonicida) causes coldwater vibriosis in marine fish such as farmed Atlantic salmon (Salmo salar), sea-farmed rainbow trout (Oncorhynchus mykiss), and captive Atlantic cod (Gadus morhua) [47]. The Gram-negative bacterium causes tissue degradation, hemolysis, and sepsis in vivo. Genome sequencing of Aliivibrio salmonicida has revealed a mosaic structure of the genome caused by large intrachromosomal rearrangements, gene acquisition, deletion, and duplication of DNA within the chromosomes and between the chromosomes and the plasmids [29].

The genome has many genes that appear to be recently acquired by HGT, and large sections of over 300 coding sequences (CDS) are disrupted by IS elements or contain point mutations causing frame shifts or premature stop codons [29]. The genomic islands (GIs) identified in the bacteria include major virulence-related genes encoding T6SS and Flp-type pilus and genes that appear to provide new functions to the bacteria. The Tad system has been proposed to represent a new subtype of T2SS and is essential for biofilm formation, colonization, and pathogenesis [48].

The genome analysis has unequivocally confirmed that Alivivibrio salmonicida has undergone extensive rearrangement of its genome by losing massive functional genes and acquiring new genes and become host-restricted, allowing the pathogen to adapt to new niches. IS expansion has been related to genome reduction in the evolution and emergence of pathogenicity [49], and accumulation of pseudogenes has been described for several other host restricted pathogens $[50,51]$.

\section{Aeromonads}

Aeromonas hydrophila and other motile aeromonads are among the most common bacteria in a variety of aquatic 
environments worldwide, including bottled water, chlorinated water, well water, sewage, and heavily polluted waters, and are frequently associated with severe disease among cultured and feral fishes, amphibians, reptiles, and birds [52]. Aeromonads are also considered serious emerging pathogens of human beings [53]. Determination of the etiology of diseases involving aeromonad infections has been complicated by the genetic, biochemical, and antigenic heterogeneity of members of this group.

The genus Aeromonas has been conveniently divided into a group of nonmotile, psychrophilic species, prominently represented by Aeromonas salmonicida, which is an obligate fish pathogen and a second group of mostly human pathogenic, motile, and mesophilic species including $A$. hydrophila.

Genome sequencing of A. hydrophila ATCC $7966^{T}$, A. salmonicida subsp. salmonicida A449, A. veronii strain B565, and A. caviae [54-57] has helped in resolving their taxonomic confusion and has brought new insights into the way these bacteria adapt to a myriad of ecological niches, their host adaptive evolution and virulence mechanisms.

Aeromonas salmonicida, the causative agent of furunculosis in salmonid and nonsalmonid fish, is a non-motile, Gram-negative bacterium; furunculosis is an important disease in wild and cultured stocks of fish inflicting heavy losses to aquaculture industry worldwide $[58,59]$. A. hydrophila causes a septicemic disease in fish known variously as "motile aeromonas septicemia" (MAS), "hemorrhagic septicemia," "ulcer disease," or "red-sore disease" [60]. The disease caused by this bacterium primarily affects freshwater fish such as catfish, several species of bass, and many species of tropical or ornamental fish. A. veronii is the causative agent of bacterial hemorrhagic septicemia in fish and is becoming a major economic problem in the fish-farming industry [23].

Genome sequencing of the fish pathogen A. salmonicida A449 has confirmed the presence of fully functional genes for a type III secretion system (T3SS) that has been shown to be required for virulence in A. salmonicida [61], and genes for a type VI secretion system (T6SS), which is disrupted by an IS element [55]. The ancestral state of the T3SS in A. salmonicida A449 is ambiguous because of the absence of the genes in A. hydrophila ATCC $7966^{T}$, while other A. hydrophila strains carry T3SS operons on the chromosome [62]. The genome contains a multitude of virulence-related genes including several types of adhesins (e.g., surface layer, flagella, and pili), toxin genes (aerolysin, hemolysin, repeats in toxin (RTX) protein, and cytolytic delta-endotoxin), secreted enzymes (protease, phospholipase, nuclease, amylase, pullulanase, and chitinase), antibiotic resistance genes (tet $A, \beta$-lactamase gene, and efflux pumps), and genes involved in iron acquisition and quorum sensing.

Most of the above genes are present in A. hydrophila ATCC $7966^{T}$ genome and an expansion of gene families (paralogs) of $\mathrm{ABC}$ transporters, two-component signal transduction systems (TCSs), transcriptional regulators, FeS cluster-binding proteins involved in energy transduction at the membrane, and methyl-accepting chemotaxis proteins (MCPs). Interestingly, transposase, resolvase, or insertion sequence element sequences were not discovered in the $A$. hydrophila ATCC $7966^{T}$ genome, whereas these have been identified in A. salmonicida and A. caviae genomes. A. salmonicida possesses 88 copies of 10 different IS elements whereas A. caviae Ae398 has only five different IS elements, and $A$. hydrophila completely lacks IS elements.

Although A. hydrophila ATCC $7966^{T}$ has been demonstrated to be the second most virulent species among Aeromonas [63], a very important virulence determinant, T3SS, which is present in A. salmonicida A449 is strikingly absent in A. hydrophila ATCC $7966^{T}$ genome. A. caviae contains many putative virulence genes, including those encoding a type 2 secretion system, an RTX toxin, and polar flagella.

The genome of A. veronii strain B565 contains some putative virulence factors, such as chitinase, RTX protein, adhesion factor, flagella, and mannose-sensitive hemagglutinin (MSHA), all of which are shared with A. hydrophila ATCC $7966^{T}$ and A. salmonicida A449. On the other hand, 346 genes including some important putative virulence factors such as hemolysins and the type III secretion protein, which are shared by the latter two species are absent in $A$. veronii strain B565.

Many unique genes in A. hydrophila ATCC $7966^{T}$ and A. salmonicida A449 are virulence genes and often form large clusters, such as the $r t x$ cluster in ATCC $7966^{T}$ and the flagellar gene cluster in A449, or are involved in mobile elements such as phages and transposons, highlighting their lateral transfer history [56].

The A. hydrophila ATCC $7966^{T}$ and A. salmonicida A449 genomes appear to be very closely related, encoding similar number of proteins with only $9 \%$ difference in gene content. However, there are many transposons, phage-related genes, and unique CDS in A. salmonicida A449 genome that are different from $A$. hydrophila ATCC $7966^{T}$ sequences, showing their distinct lineages and adaptive evolution that occurred while segregating into different species of the genus.

In sharp contrast to A. hydrophila ATCC $7966^{T}$ genome, the A. salmonicida A449 genome is characterized by the presence of large numbers of several different types of IS elements in multiple copies, with more than 20 genes being interrupted by IS elements. A. hydrophila ATCC $7966^{T}$ genome has no IS elements.

There is a higher tendency for genomic reduction in $A$. salmonicida A449 with the formation of many pseudogenes, and A. hydrophila ATCC $7966^{T}$ has only seven pseudogenes. The formation of pseudogenes has resulted in the loss of function of many genes including flagella and type IV pili, transcriptional regulators, genes encoding carbohydrate synthesis, and modification enzymes and genes for basic metabolic pathways, which are some characteristic features of pathogenomic evolution.

Thus, A. salmonicida A449 appears to have evolved much faster than A. hydrophila ATCC $7966^{T}$ through genetic rearrangements, genomic reduction, and HGT from common ancestral lineages by acquiring and forming multiple plasmids, prophages, a battery of IS elements, pseudogenes, and several individual genes and operons. 


\section{Flavobacterium}

The genus Flavobacterium includes over 30 species of which Flavobacterium psychrophilum, F. branchiophilum, and F. columnare are important disease agents for salmonids, catfish, and other cultured species $[64,65]$. Flavobacteria are significant as they are ubiquitous in the soil, freshwater, and marine environments and are noted for their novel gliding motility and ability to degrade polymeric organic matter such as hydrocarbons [66].

F. psychrophilum is the etiological agent of bacterial coldwater disease (BCWD). It is a serious fish pathogen causing substantial economic losses and rearing difficulties to both commercial and conservation aquaculture. F. psychrophilum infections are found throughout the world. Juvenile rainbow trout and coho salmon are particularly susceptible to BCWD. However, F. psychrophilum infections have been reported in a wide range of hosts, Anguilla japonica, A. anguilla, Cyprinus carpio, Carassius carassius, Tinca tinca, Plecoglossus altivelis, Perca fluviatilis, and Rutilus rutilus [64, 67]. Fry and fingerlings with BCWD often have skin ulcerations on the peduncle, anterior to the dorsal fin, at the anus, or on the lower jaw and mortalities can go up to $70 \%$ [68].

F. branchiophilum is the causative organism of bacterial gill disease (BGD) in several parts of the world [69]. This disease is characterized by explosive morbidity and mortality rates attributable to massive bacterial colonization of gill lamellar surfaces and progressive branchial pathology stemming from high rates of lamellar epithelial necrosis [70].

F. columnare (formerly Cytophaga columnaris; Flexibacter columnaris) is the causative agent of columnaris disease of salmonids and other fishes in commercial aquaculture, the ornamental fish industry, and wild fish populations worldwide [71]. Classically, during outbreaks, its morbidity and mortality rates escalate more gradually than for BGD. Additionally, unlike the pattern of necrosis in BGD, fish with columnaris will have severe necrosis of all parts of the gill as the bacterium invades inwardly [72].

The taxonomy of the three species was initially based on phenotypic characteristics and has been revised several times during the years. The latest classification based on $\mathrm{G}+\mathrm{C}$ content, DNA-ribosomal ribonucleic acid (rRNA) hybridisation, and fatty acid and protein profiles, has confirmed that all the three species now belong to the phylum/division Cytophaga-Flavobacterium-Bacteroides, family Flavobacteriaceae, and genus Flavobacterium [73].

The whole genome sequences of $F$. psychrophilum and F. branchiophilum have been published $[74,75]$. The $F$. columnare genome sequence is yet to be completed and published [76].

Prominent features of $F$. psychrophilum infection include the strong adhesion to fish epithelial tissues followed by gliding motility, rapid and mass tissue destruction, and severe muscle tissue ulcerations. Hence, the identification of multiple genes encoding secreted proteases, adhesins, and gliding motility ( $g l d)$ genes in F. psychrophilum genome indicates their possible involvement in the virulence of the pathogen. However, the gene sequence of a secreted collagenase was disrupted by an insertion sequence of the IS256 family in several strains isolated from rainbow trout [74] indicating the clonal dissemination of strains containing the disrupted gene. The F. psychrophilum seems to have horizontally acquired virulence associated genes from other unrelated bacteria. It has a hemolysin similar to the toxin VAH5, which is a virulence factor in Vibrio anguillarum [77]. It also has a gene encoding a protein that is similar to domains 1-3 of thiol-activated cytolysin family of poreforming toxins (TACYs), which has been implicated in the pathogenicity of several Gram-positive bacteria [78]. Interestingly, F. psychrophilum lacks the type III and IV secretion systems usually present in Gram-negative pathogens; but, it has genes encoding PorT and PorR proteins, which are involved in transport and anchoring of virulence factors of the bacteria $[79,80]$. In addition, the F. psychrophilum genome contains a large repertoire of genes involved in aerobic respiration, psychrotolerance, and stress response.

The sequencing of $F$. branchiophilum genome has revealed the existence of virulence mechanisms distinctly different from the closest species, F. psychrophilum. The F. branchiophilum genome has the first cholera-like toxin in a nonproteobacteria and an array of adhesins. A comparative analysis of its genome with genomes of other Flavobacterium species revealed a smaller genome size, large differences in chromosome organization, and fewer rRNA and tRNA genes, fitting with its more fastidious growth. In addition, identification of certain virulence factors, genomic islands, and CRISPR (clustered regularly interspaced short palindromic repeats) systems points to the adaptive evolution of F. branchiophilum by horizontal acquisition of genes.

\section{Edwardsiella}

The genus Edwardsiella belongs to subgroup 3 of $\gamma$ proteobacteria, encompassing a group of Gram-negative enteric bacteria pathogenic to a variety of animals [81]. Two very closely related species, Edwardsiella tarda and E. ictaluri are important fish pathogens. Both are Gramnegative motile rods that are cytochrome oxidase negative and ferment glucose with production of acid and gas. The two species can be differentiated biochemically in that $E$. tarda produces both indol and hydrogen sulfide, whereas E. ictaluri produces neither. Moreover, the two species do not cross-react serologically. E. tarda has been isolated from many warm water fishes and some coldwater fishes, whereas $E$. ictaluri has been isolated only from a few species of warm water fishes (Table 2). Additionally, E. tarda causes disease in such other animals as marine mammals, pigs, turtles, alligators, ostriches, skunks, and snakes [81]. It has also occasionally infected humans [82, 83]. In contrast, E. ictaluri is limited to fish, and survivors of epizootics probably become carriers. The geographic range of E. tarda is worldwide, whereas that of E. ictaluri is still confined to the catfish growing areas in the United States [84].

E. tarda causes a disease condition in fish called systemic hemorrhagic septicemia with swelling skin lesions as well as ulcer and necrosis in internal organs such as liver, kidney, 
spleen, and musculature [85]. It has the ability of invading and multiplying in epithelial cells and macrophages in order to subvert the host immune system and to survive in the fish [86].

E. ictaluri is the causative agent of enteric septicemia of catfish (ESC), a major disease affecting the catfish industry. The disease can manifest as an acute form that is characterized by hemorrhagic enteritis and septicemia and a chronic disease that is characterized by meningoencephalitis [87]. Gross external symptoms include hemorrhages on the body, especially around the mouth and fins. Other signs include pale gills, exophthalmia, and small ulcerations on the body [84].

The whole genome sequencing of the two species has recently been completed and published allowing comparative genomic analysis of these very important fish pathogens [88, 89]. The genome sequencing of the two closely related species E. tarda and E. ictaluri has revealed a high level of genomic plasticity with a high content of mobile genetic elements, IS elements, genomic islands, phage-like products, integrases, or recombinases. E. ictaluri displays high biochemical homogeneity with only one serotype, but possess many IS elements in the genome. In addition, highly variable $\mathrm{G}+\mathrm{C}$ content and a large quantity of variable number of tandem repeats (VNTRs) or direct repeat sequences were identified in the E. tarda genome indicating the rapid genomic evolution undergoing in the species [88]. An interesting feature is the identification of insertion sequence IS Saen 1 of Salmonella enterica serovar Enteritidis [90] in both E. tarda EIB202 and E. ictaluri 93-146 genomes. Conversely, the difference in genomic islands among the three species may partially explain their rapid evolutionary changes and diverging lineage from a common ancestor.

The E. tarda genome has a gene cluster sharing high similarities to the pvsABCDE-psuA-pvuA operon, which encodes the proteins for the synthesis and utilization of vibrioferrin, an unusual type of siderophore requiring nonribosomal peptide synthetase (NRPS) independent synthetases (NIS) and usually mediating the iron uptake systems in $V$. parahaemolyticus and V. alginolyticus [91, 92]. But E. ictaluri genome lacks siderophore biosynthesis genes, even though it possesses heme binding/transport genes.

E. tarda genome is smaller than that of E. ictaluri and other sequenced genomes of Enterobacteriaceae, justifying the hypothesis that $E$. tarda may not be present as a free living microorganism in natural waters but multiply intracellularly in protozoans and transmitted to fish, reptile, and other animals or humans [81].

The E. tarda and E. ictaluri genomes have a multitude of virulence factors including $\mathrm{P}$ pilus, type 1 fimbriae, nonfimbrial adhesins, invasins and hemagglutinins and various secretion pathways including sec-dependent transport system, the components of the main terminal branch of the general secretory pathway (GSP), the signal recognition particle (SRP), and the sec-independent twin arginine transport (Tat), T1SS, TTSS, and T6SS indicating their evolutionary fitness and ability to adapt to a variety of demanding ecological niches and harsh host intracellular environments.

\section{Yersinia ruckeri}

Yersinia ruckeri, the causal agent of enteric redmouth (ERM) disease, which is a systemic bacterial infection of fishes, but is principally known for its occurrence in rainbow trout, Salmo gairdneri [93]. Y. ruckeri was initially isolated from rainbow trout in the Hagerman Valley, Idaho, USA, in the 1950s [94] and is now widely found in fish populations throughout North America, Australia, South Africa, and Europe [95]. Outbreaks of ERM usually begin with low mortalities which slowly escalate and may result in high losses. The problem may become large-scaled if chronically infected fish are exposed to stressful conditions such as high stocking densities and poor water quality [96]. Y. ruckeri is a nonspore-forming bacterium which does not possess a capsule, but often has a flagellum [97].

Historically, Y. ruckeri is fairly homogenous in biochemical reactions. However, Y. ruckeri strains have recently been grouped into clonal types on the basis of biotype, serotype, and outer membrane protein (OMP) profiles [98]. Strains of serovars I and II [99], equivalent to serotypes O1a and O2b, respectively [100], cause most epizootic outbreaks in cultured salmonids, serovar I being predominant in rainbow trout [101]. Within serovar I, six clonal OMP types have been recognized, but only two are associated with major disease outbreaks: clonal group 5, which includes the socalled Hagerman strain and clonal group $2[98,102]$. Clonal group 5 comprises the majority of isolates, all of them motile and with a widespread distribution (Europe, North America, and South Africa). Clonal group 2 includes only nonmotile strains isolated in the UK.

More recently, multilocus sequence typing has revealed distinct phylogenetic divergence of $Y$. ruckeri from the rest of the Yersinia genus raising doubts about its taxonomic position [103]. This view has gained credibility after the genome sequencing of $Y$. ruckeri, which has a substantially reduced total genome size (3.58 to $3.89 \mathrm{Mb}$ ), compared with the 4.6 to $4.8 \mathrm{Mb}$ seen in the genus generally [104]. In addition, $Y$. ruckeri was found to be the most evolutionarily distant member of the genus with a number of features distinct from other members of the genus.

Several common Yersinia genes were missing in Y. ruckeri. These included genes involved in xylose utilization, urease activity, B12-related metabolism, and the mtnKADCBEU gene cluster that comprises the majority of the methionine salvage pathway [104]. The genomic reduction achieved by losing these and other genes is suggestive of its means of adaptation to an obligatory life style in fish hosts.

\section{Renibacterium salmoninarum}

Renibacterium salmoninarum is a small Gram-positive diplobacillus, and the causative agent of bacterial kidney disease (BKD), which is a slowly progressive, systemic infection in salmonid fishes with a protracted course and an insidious nature [105]. The pathogen can be transmitted from fish to fish [106] or from adults to their progeny via eggs [107]. Infected fish may take months to show signs of disease. bacterial kidney disease is one of the most difficult bacterial 
diseases of fish to treat [108], mainly due to its ability to evade phagocytosis and invade and survive in host cells $[109,110]$. $R$. salmoninarum is very slow growing, and it is extremely difficult to apply genetic manipulation techniques to study its gene functions.

R. salmoninarum, despite being an obligate intracellular pathogen of fish, is phylogenetically closest to the nonpathogenic environmental Arthrobacter species [51]. Based on 16S rRNA phylogenetic analysis, $R$. salmoninarum has been included in the actinomycetes subdivision and was found related to a subgroup harboring morphologically and chemotaxonomically rather heterogeneous taxa, including Arthrobacter, Micrococcus, Cellulomonas, Jonesia, Promicromonospora, Stomatococcus, and Brevibacterium [111]. In fact, Arthrobacter davidanieli is commercially used as a vaccine (commercially known as Renogen) and can provide significant cross-protection in Atlantic salmon, though not in Pacific salmon [112]. The genome sequencing of $R$. salmoninarum ATCC 33209 strain and two Arthrobacter strains, the TC1 and FB24, has revealed many interesting aspects of how this obligates fish pathogen evolved, via genomic reduction and horizontal gene acquisition, from members of the nonpathogenic genus Arthrobacter [51, 113]. A total of 1562 ORF clusters were similar in $R$. salmoninarum and Arthrobacter spp. demonstrating the genetic basis for the efficiency and cross-protection of the A. davidanieli vaccine.

There is significant genome reduction in $R$. salmoninarum genome, which is $1.44 \mathrm{Mb}$ smaller than the chromosome of TC1 and $1.55 \mathrm{Mb}$ smaller than the chromosome of FB24. The two Arthrobacter strains have several large plasmids that are not present in the ATCC 33209 strain. In addition, these plasmids do not have high levels of similarity to sequences in the R. salmoninarum chromosome [51].

The presence of many IS elements, pseudogenes, and genomic islands in $R$. salmoninarum genome coupled with a lack of restriction-modification systems contribute to the extensive disruption of ORFs as a strategy to reduce many pathways in the bacteria. Moreover, the highly homogeneous nature of $R$. salmoninarum with respect to the overall genomic structure, biochemical properties, and surface antigens $[114,115]$ points to the evolution of this pathogen towards a strictly intracellular life style.

Several virulence factors including capsular synthesis genes, heme acquisition operons, genes encoding possible hemolysins, and the poorly characterized msa genes identified in the $R$. salmoninarum genome seems to be horizontally acquired. Arthrobacter spp. lacks most of these gene sequences, thus underlining the differential evolution and adaptation of these two very closely related species to contrasting ecological niches.

\section{Streptococcus and Lactococcus}

Gram-positive cocci belonging to the genera Streptococcus and Lactococcus are increasingly being recognized as important fish pathogens all over the world [116]. There are several different species of Gram-positive cocci, including Streptococcus parauberis, S. iniae, S. agalactiae (syn.
Streptococcus difficilis), S. phocae [117, 118], Lactococcus garvieae (syn. Enterococcus seriolicida) [119], L. piscium [120-123], Vagococcus salmoninarum, and Carnobacterium piscicola [124], implicated in infectious diseases of warm water as well as cold water fishes.

Streptococcosis appears to have very few limitations in regard to geographic boundaries or host range, with outbreaks occurring in aquaculture facilities worldwide and in many different cultured species. S. iniae, S.parauberis, S. agalactiae, and L. garvieae are known as the major pathogens of streptococcosis and lactococcosis in Oncorhynchus mykiss, Seriola quinqueradiata, Siganus canaliculatus, and Tilapia spp. [125]. Recently, S. iniae and L. garvieae are also recognized as emerging zoonotic pathogens, causing diseases in both fish and human beings $[23,126]$.

$S$. iniae is a $\beta$-haemolytic, Gram-positive coccus that causes generalized septicaemia and meningoencephalitis in a variety of warm water fishes [127], whereas S. parauberis is an $\alpha$-hemolytic, Gram-positive coccus, mainly pathogenic in cultured turbot (Scophthalmus maximus) and olive flounder, Paralichthys olivaceus. L. garvieae causes a hyperacute and haemorrhagic septicemia in fishes particularly during the summer time. General pathological symptoms of streptococcosis and lactococcosis in fishes are hemorrhage, congestion, lethargy, dark pigmentation, erratic swimming, and exophthalmos with clouding of the cornea $[117,128]$.

Complete genome sequences of different strains of $S$. parauberis and L. garvieae, important pathogenic species isolated from both fish and human, have been published [129-132].

S. parauberis is recognized as the dominant etiological agent of streptococcosis in fish [117], whereas both $S$. parauberis and $S$. uberis are involved the causation of bovine mastitis in dairy cow $[133,134]$.

S. parauberis is closer to S. uberis than with other Streptococcus spp. and is biochemically and serologically indistinguishable from S. uberis [135]. Both species were earlier considered as type I and II of S. uberis, but later shown to be phylogenetically distinct and renamed the type I as $S$. uberis and type II as S. parauberis [134].

The S. parauberis strain KCTC11537BP genome size falls in the middle of the 1.8 to $2.3 \mathrm{Mb}$ range of streptococcal genomes sequenced to date and the average $\mathrm{G}+\mathrm{C}$ content of $35.6 \%$ is significantly lower than those of $S$. pyogenes [132]. About $78 \%$ of genes are shared between the genomes of $S$. parauberis strain KCTC11537BP and S. uberis NC_012004, but they differ significantly at two regions of the genome, demonstrating the genomic basis for their separation into two species.

S. parauberis genome encodes an M-like protein of S. iniae (SiM), which is an important virulence factor in S. iniae [136]. It also encodes has A and has B genes that may be involved in capsule production for resistance against phagocytosis. The genome analysis indicates that $S$. parauberis could possibly possess the ability to regulate the metabolism of more carbohydrates than other Streptococcus species and to synthesize all the aminoacids and regulatory factors required to adapt and survive in a highly hostile host environment. 
Complete genome sequences of $L$. garvieae strain UNIUD074, isolated from diseased rainbow trout in Italy, a virulent strain Lg2 (serotype KG2) and a nonvirulent strain ATCC 49156 (serotype KG+), both isolated from diseased yellowtail in Japan have recently been published $[130,131]$. In addition, genome sequence of L. garvieae strain 21881, isolated from a man suffering from septicemia has been published [129].

The strains Lg2 and ATCC 49156 have 99\% sequence identity and share 1944 orthologous genes, but are different in $24 \mathrm{Lg} 2$-specific genes that were absent in the ATCC 49156 genome. One of the Lg2-specific genes is a $16.5 \mathrm{~kb}$ capsule gene cluster, which confirms the earlier transmission electron microscopic finding that $\operatorname{Lg} 2$ is encapsulated, and ATCC 49156 is nonencapsulated [137]. In fact, the capsule gene cluster has the features of a horizontally acquired genomic island conferring virulence to the Lg2 strain but might have been lost from the ATCC 49156 strain while subculturing in the laboratory [131]. Both genomes carried three types of IS elements, prophage sequences, and integrase genes and were found smaller than those of at least five sequenced $L$. lactis genomes. The Lg2 genome lacks several aminoacid biosynthesis genes, which is a characteristic feature of pathogenic bacteria with reduced genomes. The Lg2 strain contains hemolysins, NADH oxidase and superoxide dismutase (SOD), adhesins and sortase, which are known virulence factors [137-139]. It also encodes a gene for phosphoglucomutase, a virulence factor conferring the resistance to peptide antimicrobials in S. iniae [140].

Although L. garvieae and L. lactis genomes share $75 \%$ CDS, about $25 \%$ genes are Lg2-specific hypothetical proteins and proteins of unknown functions, which may be involved in the virulence of the $\operatorname{Lg} 2$ strain. These findings indicate that L. garvieae and L. lactis have significantly diverged from the common ancestor, and the L. garvieae is evolving into a pathogenic species equipped with virulence features suitable for living in the host environment.

\section{Mycobacteria}

Chronic infections in fish caused by different species of mycobacteria have been well recognized [23, 141, 142]. Several slow growing as well as fast growing species of mycobacteria such as Mycobacterium marinum, M. fortuitum, M. chelonae, and M. avium have been isolated from wild and cultured fish suffering from mycobacteriosis in different parts of the world [143-145]. Among them, M. marinum is the most important fish pathogen, frequently isolated from a variety of fish species with granulomas [146]. It is also a known zoonotic pathogen, transmitted to man though fish handling in aquariums and aquaculture tanks, producing superficial and self-limiting lesions called "fish tank or aquarium tank granuloma" involving the cooler parts of the body such as hands, forearms, elbows, and knees [147, 148]. Although strain variation has been reported [149], there is significant intraspecies sequence homogeneity among different M. mrinum strains [150]. However, it is hypothesized that only certain strains of $M$. marinum have zoonotic potential [151]. Phylogenetic studies have shown that $M$. marinum is most closely related to M. ulcerans followed by M. tuberculosis [150]. Owing to this, M. marinum and M. tuberculosis share many virulence factors and significant pathological features and respond to similar antibiotics [152, 153]. Hence, M. marinum is also an important model organism to study the pathogenesis of tuberculosis [152, 153].

Interestingly, the genome of $M$. marinum is 50\% bigger than that of $M$. tuberculosis and seems to have acquired a number of genes encoding NRPSs and the huge repertoire of PE, PPE, and ESX systems probably by HGT [154]. Both species might have evolved differently from a common environmental mycobacteria. $M$. tuberculosis might have adapted to its host intracellular life by extensive genome reduction and $M$. marinum, by and large retained or obtained genes required for its dual lifestyle and broad-host range.

\section{Genome Sequencing to Find Novel Vaccine and Drug Targets in Fish Pathogens}

Our understanding of the molecular basis of virulence of certain well-studied fish bacterial pathogens has increased dramatically during the past decade. This has resulted from the application of recombinant DNA technology and cell biology to investigate bacterial infections, and the development of genetic techniques for identifying virulence genes.

More recently, genome sequence information of several bacterial fish pathogens has become available from genome sequencing projects. There is strong reason to believe that this understanding will be exploited to develop new interventions against fish bacterial infections.

The relevance of sequencing projects for drug and vaccine discovery is obvious. During the "pregenomic" era, the vaccine candidate genes were individually identified by tedious gene knockout studies and virulence attenuation. But now, the complete genome sequencing provides information on every virulence gene and all potential vaccine candidates, and the sequence databases will become indispensable for research in fish vaccinology and drug development.

After sequencing, the open reading frames (ORFs) are searched against available databases for sequence similarity with genes of known functions in other organisms. There are several strategies for gene annotation employing the tools of predictive bioinformatics programs combined with analyses of the published literature.

Multiple target vaccine candidate genes can be chosen and deleted simultaneously by various strategies including global transposon mutagenesis and gene replacement techniques $[155,156]$ to study their effect on virulence and essentiality. A number of important virulence determinants identified in the sequenced genome can be targeted. For example, the sortase enzyme in Gram-positive fish pathogens would be a very attractive universal vaccine and therapeutic drug target, as it mediates covalent anchoring of many surface displayed antigenic and/or virulence related proteins in Gram-positive bacteria [139]. The inactivation or inhibition of the sortase enzyme can simultaneously prevent the surface display of a number of virulence factors, thus effectively attenuating the virulence of the pathogen [110,157]. 
The availability of sequences of the complete surface antigenic repertoire of pathogens, including protein and noprotein antigens would facilitate strategies for rational design of vaccines and drugs. In addition, the recent availability of large collections of the "virulogenome" of fish bacterial pathogens will provide enormous virulence sequence information for DNA vaccination studies. The whole complement of IS elements, prophages, and pathogenicity islands that can harbor virulence, and antimicrobial resistance gene clusters can be easily identified in the genomes. The comparison of genomes of different strains of the same bacteria or closely related species can reveal how these strains or species behave differently while infecting fish hosts, thus opening exciting opportunities for functional genomic analysis of infection processes and pathogenesis. However, experimental validation of predicted functions of genes identified from sequencing projects has lagged far behind the speed of annotation, and the major challenge of researchers in the field today is to understand the functional framework of the sequenced genomes.

\section{Conclusions}

There has been a steady increase in the number of species of bacteria implicated in fish diseases. The common fish pathogenic bacterial species belong to the genera Vibrio, Aeromonas, Flavobacterium, Yersinia, Edwardsiella, Streptococcus, lactococcus, Renibacterium, and Mycobacterium [23]. However, there is growing indications that the pathogenic species spectrum as well as the geographic and host range is widening among fish pathogens [158-161], leading to the emergence of new pathogens. Unlike the situation in human and animal medicine, fish diseases pose unique and daunting challenges. Fish are always bathed in a continuous medium of water, and fish disease treatment is essentially a population medicine. In addition, the current treatment methods are largely ineffective, and the biology and genetics of most fish bacterial pathogens are poorly understood, limiting the application of modern science-based pathogen intervention strategies.

Rapid growth and expansion of genome sequencing of human and animal pathogens enabled better understanding of their biology, evolution, and host adaptation strategies, and helped in combating many major diseases. Unfortunately, such developments and progress in the genomics and functional genomics of fish pathogenic bacteria have been very slow. However, recent availability of cost-effective high-throughput sequencing technologies has set the pace of sequencing of more fish pathogenic bacteria. Genome sequencing of a number of important bacterial pathogens of fish has helped us to better understand their biology and genetics. The sequencing projects have unearthed exciting new information on the adaptive evolution of fish pathogens, for example, how the nonpathogenic and ubiquitous soil bacteria such as Arthrobacter sp. has evolved into a strictly obligate fish pathogen, $R$. salmoninarum, by shedding functional genes through genomic reduction to lead to a very cosy intracellular life style.
On the other hand, phenotypically similar strains of the same species differ in certain set of virulence gene clusters, acquired through HGT and become highly virulent. The capsule gene cluster in the L. garvieae Lg2 strain confers virulence compared to noncapsulated ATCC 49156, which lacks the gene cluster. Nonpathogenic strains acquire genomic islands from distantly related pathogenic species and emerge as new pathogens of fish.

Comparative pathogenomics of closely related bacteria has increased our knowledge of how they vary in their virulence and their ability to adapt to different ecological niches. This is clearly evident in the difference in virulence of various strains of $V$. anguillarum and $V$. vulnificus, and among the closely related species of the genus Flavobacterium. As more strain-specific sequence information on bacterial pathogens of fish becomes available, we will have a better understanding of the subtle genomic differences among strains with varying virulence characteristics.

The typical pathogen evolutionary strategy of acquiring, shuffling and shedding genes mediated by IS elements, pseudogenes, prophage sequences, and HGT is also observed in most bacterial pathogens of fish. It is certain that the new genomic information will bring paradigm changes in bacterial pathogenesis and should provide new perspectives to our current thinking on the evolutionary and adaptive strategies of aquatic bacteria and how they colonize and establish in wider ecological niches and new host species. Moreover, the identification of key virulence factors in pathogenic strains should help us design efficient drugs and vaccines to combat major bacterial pathogens of fish.

However, it should be stressed that the genomic information will provide only a snapshot of the microorganism. Highly virulent clones armed with one or more acquired virulence factors can suddenly develop from the existing harmless microorganisms in the face of environmental, antibiotic, and host-induced selective pressures.

More intriguingly, about $40 \%$ of the genes in sequenced bacterial genomes constitute new putative genes and hypothetical proteins with mysterious functions and are conserved among several different species of bacteria. Even in Escherichia coli, the most studied of all bacteria, only $54 \%$ genes have currently been functionally characterized based on experimental evidence [162]. A close scrutiny of the sequenced genomes of fish pathogens reveals that the above situation is essentially true for these pathogens as well. Although current advances in functional genomics, structural genomics and bioinformatics have contributed immensely to deciphering and extracting useful biological information from the vast genomic data, understanding and assigning functionality to the unique and new gene sequences discovered in the genomes will be the major task of genome biologists in the coming years.

\section{Acknowledgments}

This work was financially supported by various research fundings from the Ministry of Agriculture and Fisheries Wealth, Oman. 


\section{References}

[1] J. M. Rothberg and J. H. Leamon, "The development and impact of 454 sequencing," Nature Biotechnology, vol. 26, no. 10, pp. 1117-1124, 2008 .

[2] J. Zhang, R. Chiodini, A. Badr, and G. Zhang, "The impact of next-generation sequencing on genomics," Journal of Genetics and Genomics, vol. 38, no. 3, pp. 95-109, 2011.

[3] E. Pennisi, "Genome data shake tree of life," Science, vol. 280, no. 5364, pp. 672-674, 1998.

[4] W. F. Doolittle, "Phylogenetic classification and the universal tree," Science, vol. 284, no. 5423, pp. 2124-2128, 1999.

[5] W. F. Doolittle, "Lateral genomics," Trends in Cell Biology, vol. 9, no. 12, pp. M5-M8, 1999.

[6] E. Pennisi, "Is it time to uproot the tree of life?" Science, vol. 284, no. 5418, pp. 1305-1307, 1999.

[7] W. F. Doolittle, "Uprooting the tree of life," Scientific American, vol. 282, no. 2, pp. 90-95, 2000.

[8] E. V. Koonin, K. S. Makarova, and L. Aravind, "Horizontal gene transfer in prokaryotes: quantification and classification," Annual Review of Microbiology, vol. 55, pp. 709-742, 2001.

[9] N. A. Moran, "Microbial minimalism: genome reduction in bacterial pathogens," Cell, vol. 108, no. 5, pp. 583-586, 2002.

[10] A. Mira, L. Klasson, and S. G. E. Andersson, "Microbial genome evolution: sources of variability," Current Opinion in Microbiology, vol. 5, no. 5, pp. 506-512, 2002.

[11] L. Holm, "Codon usage and gene expression," Nucleic Acids Research, vol. 14, no. 7, pp. 3075-3087, 1986.

[12] L. S. Frost, R. Leplae, A. O. Summers, and A. Toussaint, "Mobile genetic elements: the agents of open source evolution," Nature Reviews Microbiology, vol. 3, no. 9, pp. 722-732, 2005.

[13] U. Dobrindt, B. Hochhut, U. Hentschel, and J. Hacker, "Genomic islands in pathogenic and environmental microorganisms," Nature Reviews Microbiology, vol. 2, no. 5, pp. 414424, 2004.

[14] U. Dobrindt and J. Hacker, "How bacterial pathogens were constructed," in Bacterial Virulence: Basic Principles, Models and Global Approaches, P. Sansonetti, Ed., pp. 3-15, Wiley$\mathrm{VCH}, \mathrm{GmbH} \& \mathrm{Co}$. KGaA, Weinheim, Germany, 2010.

[15] M. J. Pallen and B. W. Wren, "Bacterial pathogenomics," Nature, vol. 449, no. 7164, pp. 835-842, 2007.

[16] J. G. Lawrence and J. R. Roth, "Genomic flux: genome evolution by gene loss and acquisition," in Organization of the Prokaryotic Genome, R. L. Charlebois, Ed., pp. 263-289, American Society for Microbiology, Washington, DC, USA, 1999.

[17] F. P. Meyer, "Aquaculture disease and health management.," Journal of Animal Science, vol. 69, no. 10, pp. 4201-4208, 1991.

[18] C. D. Harvell, K. Kim, J. M. Burkholder et al., "Emerging marine diseases-climate links and anthropogenic factors," Science, vol. 285, no. 5433, pp. 1505-1510, 1999.

[19] R. Subasinghe, "Fish health and quarantine; review of the state of the World aquaculture," in FAO Fisheries Circular, no. 886, pp. 45-49, Rome, Italy, Food and Agriculture Organization of the United Nations, 1997.

[20] B. Hjeltnes and R. J. Roberts, "Vibriosis," in Bacterial Diseases of Fish, R. J. Roberts, N. R. Bromag, and V. Inglis, Eds., pp. 109-121, Blackwell Scientific, Oxford, UK, 1993.

[21] D. V. Lightner and R. M. Redman, "Shrimp diseases and current diagnostic methods," Aquaculture, vol. 164, no. 1-4, pp. 201-220, 1998.
[22] O. Bergh, F. Nilsen, and O. B. Samuelsen, "Diseases, prophylaxis and treatment of the Atlantic halibut Hippoglossus hippoglossus: a review," Diseases of Aquatic Organisms, vol. 48, no. 1, pp. 57-74, 2001.

[23] B. Austin and D. A. Austin, Bacterial Fish Pathogens: Disease in Farmed and Wild Fish, Springer, New York, NY, USA, 3rd edition, 1999.

[24] B. Austin and X. H. Zhang, "Vibrio harveyi: a significant pathogen of marine vertebrates and invertebrates," Letters in Applied Microbiology, vol. 43, no. 2, pp. 119-124, 2006.

[25] C. Amaro, E. G. Biosca, C. Esteve et al., "Comparative study of phenotypic and virulence properties in Vibrio vulnificus biotypes 1 and 2 obtained from a European eel farm experiencing mortalities," Diseases of Aquatic Organisms, vol. 13, pp. 29-35, 1992.

[26] E. G. Biosca, H. Llorens, E. Garay, and C. Amaro, "Presence of a capsule in Vibrio vulnificus biotype 2 and its relationship to virulence for eels," Infection and Immunity, vol. 61, no. 5, pp. 1611-1618, 1993.

[27] E. Benediktsdóttir, L. Verdonck, C. Spröer, S. Helgason, and J. Swings, "Characterization of Vibrio viscosus and Vibrio wodanis isolated at different geographical locations: a proposal for reclassification of Vibrio viscosus as Moritella viscosa comb. nov." International Journal of Systematic and Evolutionary Microbiology, vol. 50, no. 2, pp. 479-488, 2000.

[28] L. A. Actis, M. E. Tolmasky, and J. H. Crosa, "Vibriosis," in Fish Diseases and Disorders, Viral, Bacterial, and Fungal Infections, P. T. K. Woo and D. W. Bruno, Eds., vol. 3, pp. 570-605, CABI International, Oxfordshire, UK, 2nd edition, 2011.

[29] E. Hjerde, M. Lorentzen, M. T. G. Holden et al., "The genome sequence of the fish pathogen Alivibrio salmonicida strain LFI1238 shows extensive evidence of gene decay," BMC Genomics, vol. 9, article 616, 2008.

[30] P. A. Gulig, V. D. Crécy-Lagard, A. C. Wright, B. Walts, M. Telonis-Scott, and L. M. McIntyre, "SOLiD sequencing of four Vibrio vulnificus genomes enables comparative genomic analysis and identification of candidate clade-specific virulence genes," BMC Genomics, vol. 11, no. 1, article 512, 2010.

[31] H. Naka, G. M. Dias, C. C. Thompson, C. Dubay, F. L. Thompson, and J. H. Crosa, "Complete genome sequence of the marine fish pathogen Vibrio anguillarum harboring the pJM1 virulence plasmid and genomic comparison with other virulent strains of V. anguillarum and V. ordalii," Infection and Immunity, vol. 79, no. 7, pp. 2889-2900, 2011.

[32] J. L. Larsen, K. Pedersen, and I. Dalsgaard, "Vibrio anguillarum serovars associated with vibriosis in fish," Journal of Fish Diseases, vol. 17, no. 3, pp. 259-267, 1994.

[33] U. B. S. Sorensen and J. L. Larsen, "Serotyping of Vibrio anguillarum," Applied and Environmental Microbiology, vol. 51, no. 3, pp. 593-597, 1986.

[34] A. E. Toranzo and J. L. Barja, "A review of the taxonomy and seroepizootiology of Vibrio anguillarum, with special reference to aquaculture in the NorthWest Spain," Diseases of Aquatic Organisms, vol. 9, pp. 73-82, 1990.

[35] J. H. Crosa, "A plasmid associated with virulence in the marine fish pathogen Vibrio anguillarum specifies an ironsequestering system," Nature, vol. 284, no. 5756, pp. 566-568, 1980.

[36] A. E. Toranzo, J. L. Barja, S. A. Potter et al., "Molecular factors associated with virulence of marine vibrios isolated from striped bass in Chesapeake Bay," Infection and Immunity, vol. 39, no. 3, pp. 1220-1227, 1983. 
[37] M. H. Schiewe, T. J. Trust, and J. H. Crosa, "Vibrio ordalii sp. nov.: a causative agent of vibriosis in fish," Current Microbiology, vol. 6, no. 6, pp. 343-348, 1981.

[38] D. P. Ransom, C. N. Lannan, J. S. Rohovec, and J. L. Fryer, "Comparison of histopathology caused by Vibrio anguillarum and Vibrio ordalii in three species of Pacific salmon," Journal of Fish Diseases, vol. 7, pp. 107-115, 1984.

[39] K. Makino, K. Oshima, K. Kurokawa et al., "Genome sequence of Vibrio parahaemolyticus: a pathogenic mechanism distinct from that of V. cholerae," The Lancet, vol. 361, no. 9359, pp. 743-749, 2003.

[40] N. Okada, S. Matsuda, J. Matsuyama et al., "Presence of genes for type III secretion system 2 in Vibrio mimicus strains," BMC Microbiology, vol. 10, article 302, 2010.

[41] A. Alam, K. A. Miller, M. Chaand, J. S. Butler, and M. Dziejman, "Identification of Vibrio cholerae type III secretion system effector proteins," Infection and Immunity, vol. 79, no. 4, pp. 1728-1740, 2011.

[42] C. R. Osorio, S. Juiz-Rio, and M. L. Lemos, "A siderophore biosynthesis gene cluster from the fish pathogen Photobacterium damselae subsp. piscicida is structurally and functionally related to the Yersinia high-pathogenicity island," Microbiology, vol. 152, no. 11, pp. 3327-3341, 2006.

[43] E. S. Yip, B. T. Grublesky, E. A. Hussa, and K. L. Visick, "A novel, conserved cluster of genes promotes symbiotic colonization and $\sigma$-dependent biofilm formation by Vibrio fischeri," Molecular Microbiology, vol. 57, no. 5, pp. 14851498, 2005.

[44] H. S. Kim, S. J. Park, and K. H. Lee, "Role of NtrC-regulated exopolysaccharides in the biofilm formation and pathogenic interaction of Vibrio vulnificus," Molecular Microbiology, vol. 74, no. 2, pp. 436-453, 2009.

[45] E. Sanjuan, B. Fouz, J. D. Oliver, and C. Amaro, "Evaluation of genotypic and phenotypic methods to distinguish clinical from environmental Vibrio vulnificus strains," Applied and Environmental Microbiology, vol. 75, no. 6, pp. 1604-1613, 2009.

[46] N. Bisharat, D. I. Cohen, M. C. Maiden, D. W. Crook, T. Peto, and R. M. Harding, "The evolution of genetic structure in the marine pathogen, Vibrio vulnificus," Infection, Genetics and Evolution, vol. 7, no. 6, pp. 685-693, 2007.

[47] M. B. Schrøder, S. Espelid, and T. Ø. Jørgensen, "Two serotypes of Vibrio salmonicida isolated from diseased cod (Gadus morhua L.); virulence, immunological studies and vaccination experiments," Fish and Shellfish Immunology, vol. 2, no. 3, pp. 211-221, 1992.

[48] M. Tomich, P. J. Planet, and D. H. Figurski, "The tad locus: postcards from the widespread colonization island," Nature Reviews Microbiology, vol. 5, no. 5, pp. 363-375, 2007.

[49] P. Siguier, J. Filee, and M. Chandler, "Insertion sequences in prokaryotic genomes," Current Opinion in Microbiology, vol. 9, no. 5, pp. 526-531, 2006.

[50] J. Parkhill, G. Dougan, K. D. James et al., "Complete genome sequence of a multiple drug resistant Salmonella enterica serovar Typhi CT18," Nature, vol. 413, no. 6858, pp. 848-852, 2001.

[51] G. D. Wiens, D. D. Rockey, Z. Wu et al., "Genome sequence of the fish pathogen Renibacterium salmoninarum suggests reductive evolution away from an environmental Arthrobacter ancestor," Journal of Bacteriology, vol. 190, no. 21, pp. 6970-6982, 2008.

[52] A. Martin-Carnahan and S. W. Joseph, "Aeromonadaceae," in Bergey's Manual of Systematic Bacteriology, G. M. Garrity,
Ed., vol. 2, pp. 556-580, Springer, New York, NY, USA, 2nd edition, 2005.

[53] M. J. Figueras, "Clinical relevance of Aeromonas sM503," Reviews in Medical Microbiology, vol. 16, no. 4, pp. 145-153, 2005.

[54] R. Seshadri, S. W. Joseph, A. K. Chopra et al., "Genome sequence of Aeromonas hydrophila ATCC 7966T: jack of all trades," Journal of Bacteriology, vol. 188, no. 23, pp. 82728282, 2006

[55] M. E. Reith, R. K. Singh, B. Curtis et al., "The genome of Aeromonas salmonicida subsp. salmonicida A449: Insights into the evolution of a fish pathogen," BMC Genomics, vol. 9, article 427, 2008.

[56] Y. Li, Y. Liu, Z. Zhou et al., "Complete genome sequence of Aeromonas veronii strain B565," Journal of Bacteriology, vol. 193, no. 13, pp. 3389-3390, 2011.

[57] S. A. Beatson, M. D. G. de Luna, N. L. Bachmann et al., "Genome sequence of the emerging pathogen Aeromonas caviae," Journal of Bacteriology, vol. 193, no. 5, pp. 1286-1287, 2011.

[58] E. M. Bernoth, "Furunculosis: the history of the diseases and of disease research," in Furunculosis, Multidisciplinary Fish Disease Research, E. M. Bernoth, A. E. Ellis, P. J. Midtlyng, G. Olivier, and P. Smith, Eds., pp. 1-20, Academic Press, London, UK, 1997.

[59] M. Hiney and G. Olivier, "Furunculosis (Aeromonas salmonicida)," in Fish Diseases and Disorders III: Viral, Bacterial and Fungal Infections, P. T. K. Woo and D. W. Bruno, Eds., pp. 341-425, CAB Publishing, Oxford, UK, 1999.

[60] C. Paniagua, O. Rivero, J. Anguita, and G. Naharro, "Pathogenicity factors and virulence for rainbow trout (Salmo gairdneri) of motile Aeromonas spp. isolated from a river," Journal of Clinical Microbiology, vol. 28, no. 2, pp. 350355, 1990.

[61] S. E. Burr, D. Pugovkin, T. Wahli, H. Segner, and J. Frey, "Attenuated virulence of an Aeromonas salmonicida subsp. salmonicida type III secretion mutant in a rainbow trout model," Microbiology, vol. 151, no. 6, pp. 2111-2118, 2005.

[62] J. Sha, L. Pillai, A. A. Fadl, C. L. Galindo, T. E. Erova, and A. K. Chopra, "The type III secretion system and cytotoxic enterotoxin alter the virulence of Aeromonas hydrophila," Infection and Immunity, vol. 73, no. 10, pp. 6446-6457, 2005.

[63] J. M. Janda and R. P. Kokka, "The pathogenicity of Aeromonas strains relative to genospecies and phenospecies identification," FEMS Microbiology Letters, vol. 90, no. 1, pp. 29-33, 1991.

[64] J. Madetoja, I. Dalsgaard, and T. Wiklund, "Occurrence of Flavobacterium psychrophilum in fish-farming environments," Diseases of Aquatic Organisms, vol. 52, no. 2, pp. 109$118,2002$.

[65] A. Nematollahi, A. Decostere, F. Pasmans, and F. Haesebrouck, "Flavobacterium psychrophilum infections in salmonid fish," Journal of Fish Diseases, vol. 26, no. 10, pp. 563-574, 2003.

[66] J. G. Leahy and R. R. Colwell, "Microbial degradation of hydrocarbons in the environment," Microbiological Reviews, vol. 54, no. 3, pp. 305-315, 1990.

[67] J. Lehmann, D. Mock, F. J. Stuerenberg, and J. F. Bernardet, "First isolation of Cytophaga psychrophila from a systemic disease in eel and cyprinids," Diseases of Aquatic Organisms, vol. 10, pp. 217-220, 1991. 
[68] R. A. Holt, Cytophaga psychrophila, the causative agent of bacterial cold-water disease in salmonid fish, Ph.D. thesis, Oregon State University, Corvallis, Ore, USA, 1987.

[69] G. J. Heo, K. Kasai, and H. Wakabayashi, "Occurrence of Flavobacterium branchiophila associated with bacterial gill disease at a trout hatchery," Fish Pathology, vol. 25, pp. 99$105,1990$.

[70] V. E. Ostland, J. S. Lumsden, D. D. MacPhee, and H. W. Ferguson, "Characteristics of Flavobacterium branchiophilum, the cause of salmonid bacterial gill disease in Ontario," Journal of Aquatic Animal Health, vol. 6, no. 1, pp. 13-26, 1994.

[71] J. F. Bernardet, "Flexibacter columnaris: first description in France and comparison with bacterial strains from other origins," Diseases of Aquatic Organisms, vol. 6, pp. 37-44, 1989.

[72] D. J. Speare and H. W. Ferguson, "Clinical and pathological features of common gill diseases of cultured salmonids in Ontario," Canadian Veterinary Journal, vol. 30, pp. 882-887, 1989.

[73] J. F. Bernardet, P. Segers, M. Vancanneyt, F. Berthe, K. Kersters, and P. Vandamme, "Cutting a gordian knot: emended classification and description of the genus Flavobacterium, emended description of the family Flavobacteriaceae, and proposal of Flavobacterium hydatis nom. nov. (basonym, Cytophaga aquatilis Strohl and Tait 1978)," International Journal of Systematic Bacteriology, vol. 46, no. 1, pp. 128-148, 1996.

[74] E. Duchaud, M. Boussaha, V. Loux et al., "Complete genome sequence of the fish pathogen Flavobacterium psychrophilum," Nature Biotechnology, vol. 25, no. 7, pp. 763769, 2007.

[75] M. Touchon, P. Barbier, J. F. Bernardet et al., "Complete genome sequence of the fish pathogen Flavobacterium branchiophilum," Applied and Environmentl Microbiology, vol. 77, no. 21, pp. 7656-7662, 2011.

[76] M. L. Lawrence, A. Karsi, H. C. Tekedar et al., "Comparative genomics of Flavobacterium columnare isolates from two genetic divisions and with different pathogenic potential for channel catfish (Ictalurus punctatus)," in Proceedings of the Conference on FLAVOBACTERIUM, Paris, France, September 2009.

[77] C. Rodkhum, I. Hirono, J. H. Crosa, and T. Aoki, "Four novel hemolysin genes of Vibrio anguillarum and their virulence to rainbow trout," Microbial Pathogenesis, vol. 39, no. 4, pp. 109-119, 2005.

[78] M. Palmer, "The family of thiol-activated, cholesterolbinding cytolysins," Toxicon, vol. 39, no. 11, pp. 1681-1689, 2001.

[79] M. Shoji, D. B. Ratnayake, Y. Shi et al., "Construction and characterization of a nonpigmented mutant of Porphyromonas gingivalis: Cell surface polysaccharide as an anchorage for gingipanis," Microbiology, vol. 148, no. 4, pp. 1183-1191, 2002.

[80] K. Sato, E. Sakai, P. D. Veith et al., "Identification of a new membrane-associated protein that influences transport/maturation of gingipains and adhesins of Porphyromonas gingivalis," The Journal of Biological Chemistry, vol. 280, no. 10, pp. 8668-8677, 2005.

[81] S. L. Abbott and J. M. Janda, "The genus Edwardsiella," Prokaryotes, vol. 6, pp. 72-89, 2006.

[82] J. E. Clarridge, D. M. Musher, V. Fanstein, and R. J. Wallace Jr., "Extra-intestinal human infection caused by Edwardsiella tarda," Journal of Clinical Microbiology, vol. 11, no. 5, pp. 511-514, 1980.

[83] P. Nagel, A. Serritella, and T. J. Layden, "Edwardsiella tarda gastroenteritis associated with a pet turtle," Gastroenterology, vol. 82, no. 6, pp. 1436-1437, 1982.

[84] W. A. Rogers, "Edwardsiellosis in fishes," in Antigens of Fish Pathogens. Les Antigenes des Microorganisms Pathogenes des Poissons, D. P. Anderson, M. Dorson, and Ph. Dubourget, Eds., pp. 153-159, Fondation Marcel Merieux, Lyon, France, 1983.

[85] F. P. Meyer and G. L. Bullock, "Edwardsiella tarda, a new pathogen of channel catfish (Ictalurus punctatus)," Applied Microbiology, vol. 25, no. 1, pp. 155-156, 1973.

[86] S. H. M. Ling, X. H. Wang, L. Xie, T. M. Lim, and K. Y. Leung, "Use of green fluorescent protein (GFP) to study the invasion pathways of Edwardsiella tarda in in vivo and in vitro fish models," Microbiology, vol. 146, no. 1, pp. 7-19, 2000.

[87] J. C. Newton, L. G. Wolfe, J. M. Grizzle, and J. A. Plumb, "Pathology of experimental enteric septicaemia in channel catfish, Ictalurus punctatus (Rafinesque), following immersion-exposure to Edwardsiella ictaluri," Journal of Fish Diseases, vol. 12, no. 4, pp. 335-347, 1989.

[88] Q. Wang, M. Yang, J. Xiao et al., "Genome sequence of the versatile fish pathogen Edwardsiella tarda provides insights into its adaptation to broad host ranges and intracellular niches," PLoS One, vol. 4, no. 10, Article ID e7646, 2009.

[89] M. L. Williams, A. F. Gillaspy, D. W. Dyer et al., "Genome sequence of Edwardsiella ictaluri 93-146, a strain associated with a natural channel catfish outbreak of enteric septicemia of catfish," Journal of Bacteriology, vol. 194, no. 3, pp. 740741, 2012.

[90] S. R. Partridge and R. M. Hall, “The IS1111 family members IS4321 and IS5075 have sub-terminal inverted repeats and target the terminal inverted repeats of $\operatorname{Tn} 21$ family transposons," Journal of Bacteriology, vol. 185, no. 21, pp. 63716384, 2003.

[91] T. Tanabe, T. Funahashi, H. Nakao, S. I. Miyoshi, S. Shinoda, and S. Yamamoto, "Identification and characterization of genes required for biosynthesis and transport of the siderophore vibrioferrin in Vibrio parahaemolyticus," Journal of Bacteriology, vol. 185, no. 23, pp. 6938-6949, 2003.

[92] Q. Wang, Q. Liu, Y. Ma, L. Zhou, and Y. Zhang, "Isolation, sequencing and characterization of cluster genes involved in the biosynthesis and utilization of the siderophore of marine fish pathogen Vibrio alginolyticus," Archives of Microbiology, vol. 188, no. 4, pp. 433-439, 2007.

[93] M. D. Furones, C. J. Rodgers, and C. B. Munn, "Yersinia ruckeri, the causal agent of enteric redmouth disease (ERM) in fish," Annual Review of Fish Diseases, vol. 3, no. C, pp. 105125, 1993.

[94] R. R. Rucker, "Redmouth disease of rainbow trout (Salmo gairdneri)," Bulletin de l'Office International des Epizooties, vol. 65, no. 5, pp. 825-830, 1966.

[95] E. Tobback, A. Decostere, K. Hermans, F. Haesebrouck, and K. Chiers, "Yersinia ruckeri infections in salmonid fish," Journal of Fish Diseases, vol. 30, no. 5, pp. 257-268, 2007.

[96] M. T. Horne and A. C. Barnes, "Enteric redmouth disease ( $Y$. ruckeri)," in Fish Diseases and Disorders: Viral, Bacterial and Fungal Infections, P. T. K. Woo and D. W. Bruno, Eds., vol. 3, pp. 455-477, CABI Publishing, Oxfordshire, UK, 1999.

[97] A. J. Ross, R. R. Rucker, and W. H. Ewing, "Description of a bacterium associated with redmouth disease of rainbow trout 
(Salmo gairdneri)," Canadian Journal of Microbiology, vol. 12, no. 4, pp. 763-770, 1966.

[98] R. L. Davies, "Virulence and serum-resistance in different clonal groups and serotypes of Yersinia ruckeri," Veterinary Microbiology, vol. 29, no. 3-4, pp. 289-297, 1991.

[99] R. M. V. Stevenson and D. W. Airdrie, "Serological variation among Yersinia ruckeri strains," Journal of Fish Diseases, vol. 7, pp. 247-254, 1984.

[100] J. L. Romalde, B. Magarinos, J. L. Barja, and A. E. Toranzo, "Antigenic and molecular characterization of Yersinia ruckeri proposal for a new intraspecies classification," Systematic and Applied Microbiology, vol. 16, no. 3, pp. 411-419, 1993.

[101] R. M. Stevenson, "Immunization with bacterial antigens: yersiniosis," Developments in Biological Standardization, vol. 90, pp. 117-124, 1997.

[102] R. L. Davies, "Yersinia ruckeri produces four iron-regulated proteins but does not produce detectable siderophores," Journal of Fish Diseases, vol. 14, pp. 563-570, 1991.

[103] M. Kotetishvili, A. Kreger, G. Wauters, J. G. Morris, A. Sulakvelidze, and O. C. Stine, "Multilocus sequence typing for studying genetic relationships among Yersinia species," Journal of Clinical Microbiology, vol. 43, no. 6, pp. 2674-2684, 2005.

[104] P. E. Chen, C. Cook, A. C. Stewart et al., "Genomic characterization of the Yersinia genus," Genome Biology, vol. 11, no. 1, article R1, 2010.

[105] J. E. Sanders and J. L. Fryer, "Renibacterium salmoninarum gen. nov., sp. nov., the causative agent of bacterial kidney disease in salmonid fishes," International Journal of Systematic Bacteriology, vol. 30, no. 2, pp. 496-502, 1980.

[106] D. L. Mitchum and L. E. Sherman, "Transmission of bacterial kidney disease from wild to stocked hatchery trout," Canadian Journal of Fisheries and Aquatic Sciences, vol. 38, pp. 547-551, 1981.

[107] G. L. Bullock, Bacterial Kidney Disease of Salmonid Fishes Caused by Renibacterium salmoninarum, no. 60, U.S. Fish and Wildlife Service, Fish Disease Leaflet, Washington, DC, USA, 1980.

[108] K. E. Wolf and C. E. Dunbar, "Test of 34 therapeutic agents for control of kidney disease in trout," Transactions of American Fisheries Society, vol. 88, pp. 117-124, 1959.

[109] S. K. Gutenberger, J. R. Duimstra, J. S. Rohovec, and J. L. Fryer, "Intracellular survival of Renibacterium salmoninarum in trout mononuclear phagocytes," Disease of Aquatic Organisms, vol. 28, no. 2, pp. 93-106, 1997.

[110] P. S. Sudheesh, S. Crane, K. D. Cain, and M. S. Strom, "Sortase inhibitor phenyl vinyl sulfone inhibits Renibacterium salmoninarum adherence and invasion of host cells," Diseases of Aquatic Organisms, vol. 78, no. 2, pp. 115-127, 2007.

[111] E. Stackebrandt, U. Wehmeyer, H. Nader, and F. Fiedler, "Phylogenetic relationship of the fish pathogenic Renibacterium salmoninarum to Arthrobacter, Micrococcus and related taxa," FEMS Microbiology Letters, vol. 50, no. 2-3, pp. 117-120, 1988.

[112] K. Salonius, C. Siderakis, A. M. MacKinnon, and S. G. Griffiths, "Use of Arthrobacter davidanieli as a live vaccine against Renibacterium salmoninarum and Piscirickettsia salmonis in salmonids," Developments in Biologicals, vol. 121, pp. 189197, 2005.

[113] E. F. Mongodin, N. Shapir, S. C. Daugherty et al., "Secrets of soil survival revealed by the genome sequence of Arthrobacter aurescens TC1," PLoS Genetics, vol. 2, no. 12, article e214, 2006.
[114] R. G. Getchell, J. S. Rohovec, and J. L. Fryer, "Comparison of Renibacterium salmoninarum isolates by antigenic analysis," Fish Pathology, vol. 20, pp. 149-159, 1985.

[115] F. Fiedler and R. Draxl, "Biochemical and immunochemical properties of the cell surface of Renibacterium salmoninarum," Journal of Bacteriology, vol. 168, no. 2, pp. 799-804, 1986.

[116] T. Kitao, "Streptococcal infections," in Bacterial Disease of Fish, V. Inglis, R. J. Roberts, and N. R. Bromage, Eds., pp. 196-210, Blackwell Scientific, Oxford, UK, 1993.

[117] A. Domenech, J. F. Fernandez-Garayzabal, C. Pasqual et al., "Streptococcosis in cultured turbot, Scophthalmus maximus (L.), associated with Streptococcus parauberis," Journal of Fish Diseases, vol. 19, pp. 33-38, 1996.

[118] J. L. Romalde, C. Ravelo, I. Valdés et al., "Streptococcus phocae, an emerging pathogen for salmonid culture," Veterinary Microbiology, vol. 130, no. 1-2, pp. 198-207, 2008.

[119] D. Vendrell, J. L. Balcázar, I. Ruiz-Zarzuela, I. de Blas, O. Gironés, and J. L. Múzquiz, "Lactococcus garvieae in fish: a review," Comparative Immunology, Microbiology and Infectious Diseases, vol. 29, no. 4, pp. 177-198, 2006.

[120] M. D. Collins, J. A. E. Farrow, B. A. Phillips, and O. Kandler, "Streptococcus garvieae sp. nov. and Streptococcus plantarum sp. nov.," Journal of General Microbiology, vol. 129, no. 11, pp. 3427-3431, 1983.

[121] A. M. Williams, J. L. Fryer, and M. D. Collins, "Lactococcus piscium sp. nov. a new Lactococcus species from salmonid fish," FEMS Microbiology Letters, vol. 68, no. 1-2, pp. 109113, 1990.

[122] A. Domenech, J. Prieta, J. F. Fernandez-Garayzabal et al., "Phenotypic and phylogenetic evidence for a close relationship between Lactococcus garvieae and Enterococcus seriolicida," Microbiologia SEM, vol. 9, no. 1, pp. 63-68, 1993.

[123] A. Eldar, C. Ghittino, L. Asanta et al., "Enterococcus seriolicida is a junior synonym of Lactococcus garvieae, a causative agent of septicemia and meningoencephalitis in fish," Current Microbiology, vol. 32, no. 2, pp. 85-88, 1996.

[124] S. Wallbanks, A. J. Martinez-Murcia, J. L. Fryer, B. A. Phillips, and M. D. Collins, "16S rRNA sequence determination for members of the genus Carnobacterium and related lactic acid bacteria and description of Vagococcus salmoninarum sp. nov.," International Journal of Systematic Bacteriology, vol. 40, no. 3, pp. 224-230, 1990.

[125] E. S. Bromage and L. Owens, "Infection of barramundi Lates calcarifer with Streptococcus iniae: effects of different routes of exposure," Diseases of Aquatic Organisms, vol. 52, no. 3, pp. 199-205, 2002.

[126] J. A. Elliott, M. D. Collins, N. E. Pigott, and R. R. Facklam, "Differentiation of Lactococcus lactis and Lactococcus garvieae from humans by comparison of whole-cell protein patterns," Journal of Clinical Microbiology, vol. 29, no. 12, pp. 27312734, 1991.

[127] R. P. Perera, S. K. Johnson, M. D. Collins, and D. H. Lewis, "Streptococcus iniae associated with mortality of Tilapia nilotica X T.aurea hybrids," Journal of Aquatic Animal Health, vol. 6, no. 4, pp. 335-340, 1994.

[128] R. Kusuda, K. Kawai, F. Salati, C. R. Banner, and J. L. Fryer, "Enterococcus seriolicida sp. nov., a fish pathogen," International Journal of Systematic Bacteriology, vol. 41, no. 3, pp. 406-409, 1991.

[129] M. Aguado-Urda, G. H. López-Campos, M. M. Blanco et al., "Genome sequence of Lactococcus garvieae 21881, isolated in a case of human septicemia," Journal of Bacteriology, vol. 193, no. 15, pp. 4033-4034, 2011. 
[130] P. Reimundo, M. Pignatelli, L. D. Alcaraz, G. D’Auria, A. Moya, and J. A. Guijarro, "Genome sequence of Lactococcus garvieae UNIUD074, isolated in Italy from a lactococcosis outbreak," Journal of Bacteriology, vol. 193, no. 14, pp. 36843685, 2011.

[131] H. Morita, H. Toh, K. Oshima et al., "Complete genome sequence and comparative analysis of the fish pathogen Lactococcus garvieae," PLoS One, vol. 6, no. 8, Article ID e23184, 2011.

[132] S. W. Nho, J. I. Hikima, I. S. Cha et al., "Complete genome sequence and immunoproteomic analyses of the bacterial fish pathogen Streptococcus parauberis," Journal of Bacteriology, vol. 193, no. 13, pp. 3356-3366, 2011.

[133] J. L. Watts, "Etiological agents of bovine mastitis," Veterinary Microbiology, vol. 16, no. 1, pp. 41-66, 1988.

[134] A. M. Williams and M. D. Collins, "Molecular taxonomic studies on Streptococcus uberis types I and II. Description of Streptococcus parauberis sp. nov.", Journal of Applied Bacteriology, vol. 68, no. 5, pp. 485-490, 1990.

[135] R. W. Bentley, J. A. Leigh, and M. D. Collins, "Intrageneric structure of Streptococcus based on comparative analysis of small-subunit rRNA sequences," International Journal of Systematic Bacteriology, vol. 41, no. 4, pp. 487-494, 1991.

[136] J. B. Locke, R. K. Aziz, M. R. Vicknair, V. Nizet, and J. T. Buchanan, "Streptococcus iniae M-like protein contributes to virulence in fish and is a target for live attenuated vaccine development," PLoS One, vol. 3, no. 7, Article ID e2824, 2008.

[137] M. Kawanishi, T. Yoshida, M. Kijima et al., "Characterization of Lactococcus garvieae isolated from radish and broccoli sprouts that exhibited a KG+ phenotype, lack of virulence and absence of a capsule," Letters in Applied Microbiology, vol. 44, no. 5, pp. 481-487, 2007.

[138] T. J. Mitchell, “The pathogenesis of streptococcal infections: from tooth decay to meningitis," Nature Reviews. Microbiology, vol. 1, no. 3, pp. 219-230, 2003.

[139] L. A. Marraffini, A. C. Dedent, and O. Schneewind, "Sortases and the art of anchoring proteins to the envelopes of gram-positive bacteria," Microbiology and Molecular Biology Reviews, vol. 70, no. 1, pp. 192-221, 2006.

[140] J. T. Buchanan, J. A. Stannard, X. Lauth et al., "Streptococcus iniaephosphoglucomutase is a virulence factor and a target for vaccine development," Infection and Immunity, vol. 73, no. 10, pp. 6935-6944, 2005.

[141] G. N. Frerichs, "Acid-fast fish pathogens," in Bacterial Diseases of Fish, V. Inglis, R. J. Roberts, and N. R. Bromage, Eds., pp. 217-233, Blackwell Scientific, Oxford, UK, 1993.

[142] E. J. Noga, Fish disease diagnosis and treatment, Mosby, St. Louis, Mo, USA, 1996.

[143] L. G. Wayne, G. P. Kubica et al., "Genus Mycobacterium Lehmann and Neumann 1896, 363AL," in Bergey's Manual of Systematic Bacteriology, P. H. A. Sneath, N. S. Mair, M. E. Sharpe, and J. G. Holt, Eds., vol. 2, pp. 1436-1457, Williams \& Wilkins, Baltimore, Md, USA, 1986.

[144] C. O. Thoen and T. A. Schliesser, "Mycobacterial infections in cold-blooded animals," in The Mycobacteria, G. P. Kubica and L. G. Wayne, Eds., part B, p. 1471, 1st edition, 1984.

[145] G. E. Sanders and L. E. Swaim, "Atypical piscine Mycobacteriosis in Japanese medaka (Oryzias latipes)," Comparative Medicine, vol. 51, no. 2, pp. 171-175, 2001.

[146] M. K. Stoskopf, Fish Medicine, WB Saunders, Philadelphia, Pa, USA, 1993.

[147] D. T. Smith and H. P. Willett, "Other Mycobacterium species," in Zinsser Microbiology, K. Joklik, H. P. Willet, and D. B.
Amos, Eds., pp. 674-698, Appleton-Century-Crofts, New York, NY, USA, 17th edition, 1980.

[148] D. Huminer, S. D. Pitlik, C. Block et al., "Aquarium-borne Mycobacterium marinum skin infection. Report of a case and review of the literature," Archives of Dermatology, vol. 122, no. 6, pp. 698-703, 1986.

[149] M. Ucko, A. Colorni, H. Kvitt, A. Diamant, A. Zlotkin, and W. R. Knibb, "Strain variation in Mycobacterium marinum fish isolates," Applied and Environmental Microbiology, vol. 68, no. 11, pp. 5281-5287, 2002.

[150] M. J. Yip, J. L. Porter, J. A. M. Fyfe et al., "Evolution of Mycobacterium ulcerans and other mycolactone-producing mycobacteria from a common Mycobacterium marinum progenitor," Journal of Bacteriology, vol. 189, no. 5, pp. 20212029, 2007.

[151] M. Ucko and A. Colorni, "Mycobacterium marinum infections in fish and humans in Israel," Journal of Clinical Microbiology, vol. 43, no. 2, pp. 892-895, 2005.

[152] H. E. Volkman, H. Clay, D. Beery, J. C. W. Chang, D. R. Sherman, and L. Ramakrishnan, "Tuberculous granuloma formation is enhanced by a Mycobacterium virulence determinant," PLoS Biology, vol. 2, no. 11, article e367, 2004.

[153] L. E. Swaim, L. E. Connolly, H. E. Volkman, O. Humbert, D. E. Born, and L. Ramakrishnan, "Mycobacterium marinum infection of adult zebrafish causes caseating granulomatous tuberculosis and is moderated by adaptive immunity," Infection and Immunity, vol. 74, no. 11, pp. 6108-6117, 2006.

[154] T. P. Stinear, T. Seemann, P. F. Harrison et al., "Insights from the complete genome sequence of Mycobacterium marinum on the evolution of Mycobacterium tuberculosis," Genome Research, vol. 18, no. 5, pp. 729-741, 2008.

[155] J. McFadden, "Recombination in mycobacteria," Molecular Microbiology, vol. 21, no. 2, pp. 205-211, 1996.

[156] N. R. Salama, B. Shepherd, and S. Falkow, "Global transposon mutagenesis and essential gene analysis of Helicobacter pylori," Journal of Bacteriology, vol. 186, no. 23, pp. 79267935, 2004.

[157] P. Cossart and R. Jonquières, "Sortase, a universal target for therapeutic agents against Gram-positive bacteria?" Proceedings of the National Academy of Sciences of the United States of America, vol. 97, no. 10, pp. 5013-5015, 2000.

[158] M. Maher, R. Palmer, F. Gannon, and T. Smith, "Relationship of a novel bacterial fish pathogen to Streptobacillus monilifomris and the fusobacteria group, based on 16S ribosomal RNA analysis," Systematic and Applied Microbiology, vol. 18, no. 1, pp. 79-84, 1995.

[159] J. L. Fryer and M. J. Mauel, "The rickettsia: an emerging group of pathogens in fish," Emerging Infectious Diseases, vol. 3, no. 2, pp. 137-144, 1997.

[160] T. H. Birkbeck, L. A. Laidler, A. N. Grant, and D. I. Cox, "Pasteurella skyensis sp. nov., isolated from Atlantic salmon (Salmo salar L.)," International Journal of Systematic and Evolutionary Microbiology, vol. 52, no. 3, pp. 699-704, 2002.

[161] C. Michel, J. F. Bernardet, P. Daniel, S. Chilmonczyk, M. Urdaci, and P. de Kinkelin, "Clinical and aetiological aspects of a summer enteritic syndrome associated with the sporulating segmented filamentous bacterium "Candidatus Arthromitus" in farmed rainbow trout, Oncorhynchus mykiss (Walbaum)," Journal of Fish Diseases, vol. 25, no. 9, pp. 533543, 2002.

[162] M. Riley, T. Abe, M. B. Arnaud et al., "Escherichia coli K12: a cooperatively developed annotation snapshot-2005," Nucleic Acids Research, vol. 34, no. 1, pp. 1-9, 2006. 

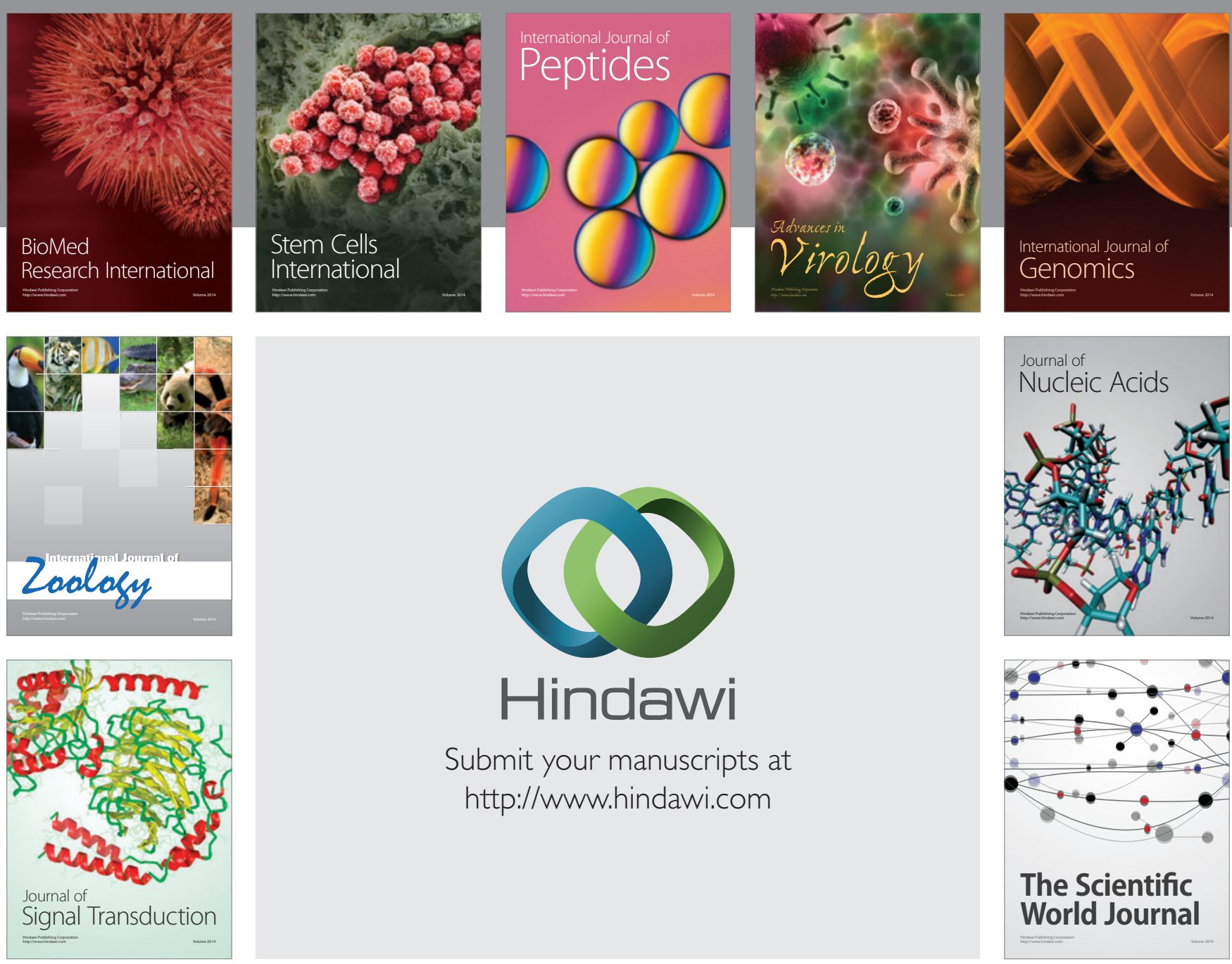

Submit your manuscripts at

http://www.hindawi.com
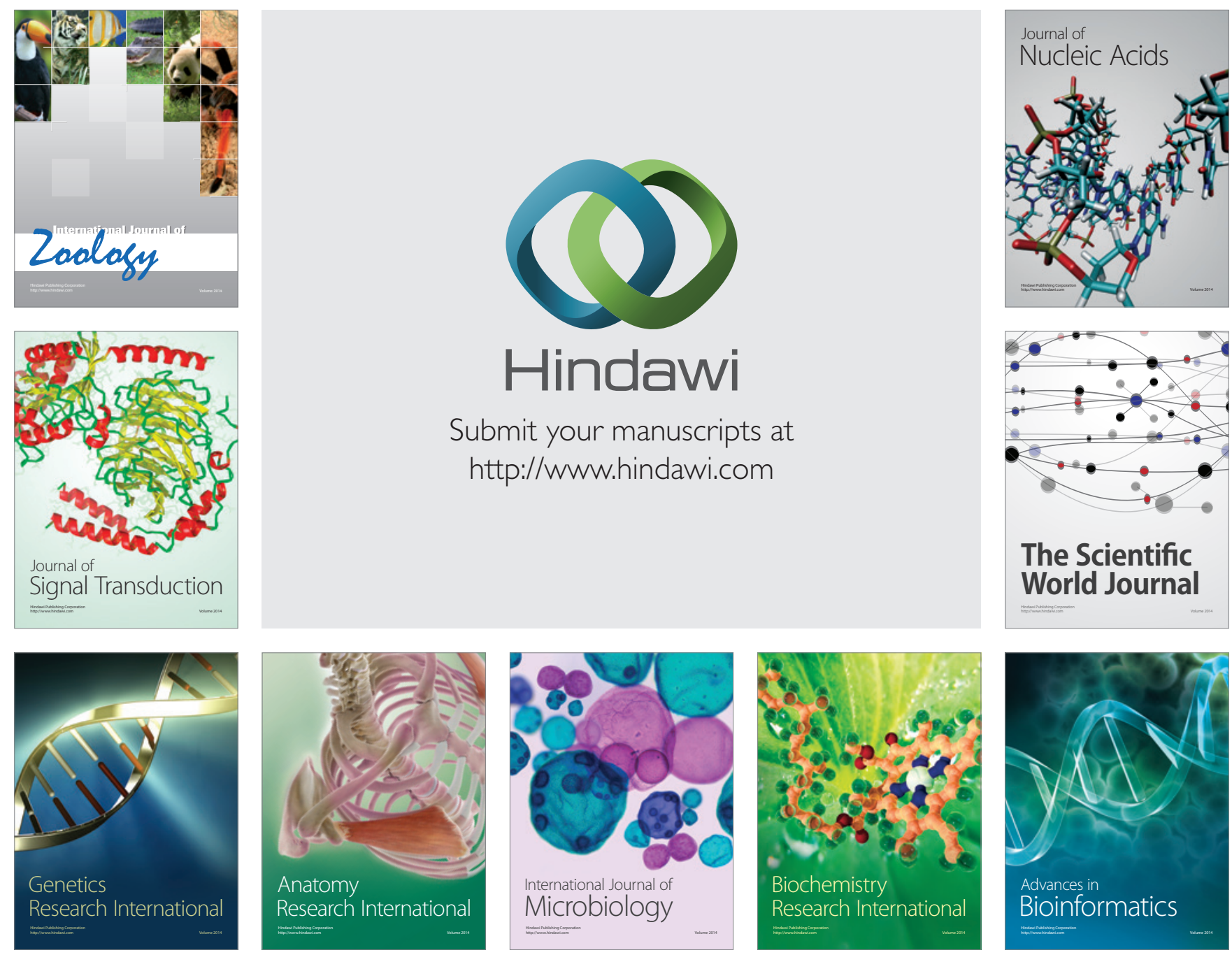

The Scientific World Journal
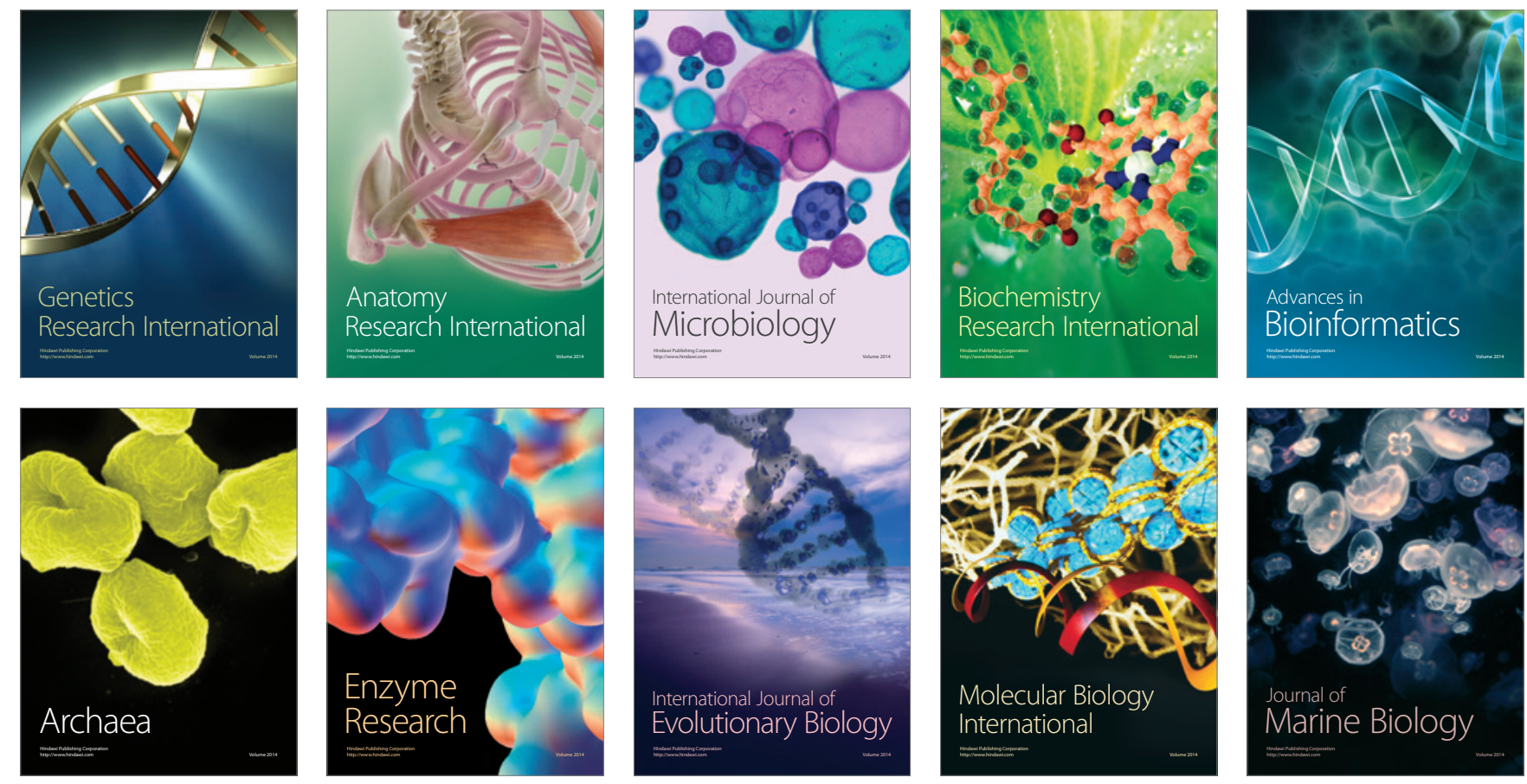